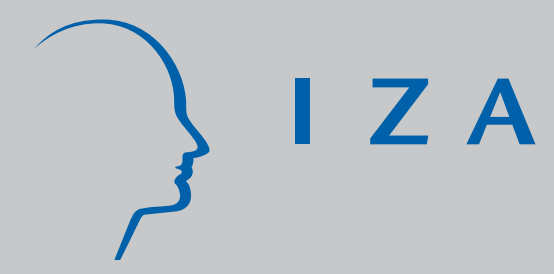

IZADP No. 2891

Modeling Migration Dynamics of Immigrants:

The Case of The Netherlands

Govert E. Bijwaard

J une 2007 


\title{
Modeling Migration Dynamics of Immigrants: The Case of The Netherlands
}

\author{
Govert E. Bijwaard \\ Erasmus University Rotterdam \\ and IZA
}
Discussion Paper No. 2891
June 2007

IZA

P.O. Box 7240

53072 Bonn

Germany
Phone: +49-228-3894-0
Fax: +49-228-3894-180
E-mail: iza@iza.org

\begin{abstract}
Any opinions expressed here are those of the author(s) and not those of the institute. Research disseminated by IZA may include views on policy, but the institute itself takes no institutional policy positions.

The Institute for the Study of Labor (IZA) in Bonn is a local and virtual international research center and a place of communication between science, politics and business. IZA is an independent nonprofit company supported by Deutsche Post World Net. The center is associated with the University of Bonn and offers a stimulating research environment through its research networks, research support, and visitors and doctoral programs. IZA engages in (i) original and internationally competitive research in all fields of labor economics, (ii) development of policy concepts, and (iii) dissemination of research results and concepts to the interested public.
\end{abstract}

IZA Discussion Papers often represent preliminary work and are circulated to encourage discussion. Citation of such a paper should account for its provisional character. A revised version may be available directly from the author. 


\section{ABSTRACT}

\section{Modeling Migration Dynamics of Immigrants: The Case of The Netherlands ${ }^{*}$}

In this paper we analyze the demographic factors that influence the migration dynamics of recent immigrants to The Netherlands. We show how we can allow for both permanent and temporary migrants. Based on data from Statistics Netherlands we analyze both the departure and the return from abroad for recent non-Dutch immigrants to The Netherlands. Results disclose differences among migrants by migration motive and by country of origin and lend support to our analytical framework. Combining both models, for departure and returning, provides the probability that a specific migrant ends-up in The Netherlands. It also yields a framework for predicting the migration dynamics over the life-cycle. We can conclude that for a complete view of the migration dynamics it is important to allow for both permanent (stayers) migrants and temporary (movers) migrants and that return from abroad should not be neglected.

JEL Classification: F22, J10, C41

Keywords: return migration, migration dynamics

Corresponding author:

Govert E. Bijwaard

Econometric Institute

Erasmus University

P.O. Box 1738

3000 DR Rotterdam

Netherlands

E-mail: bijwaard@few.eur.nl

\footnotetext{
* This research is based on a collaboration with Statistics Netherlands and financially supported by the Netherlands Organization for Scientific Research (NWO) nr. 451-04-011. I thank Ruben van Gaalen, Han Nicolaas, Arno Sprangers, Joop Hartog, participants at ESPE 2006 conference and at Aarhus University seminar for valuable comments.
} 


\section{Introduction}

The early theories on migration explain the migration flows as a result of wage differentials or through differences in unemployment levels. Given the great and persistent wage and unemployment gaps between most developing countries and the Western World, these conventional migration theories are unable to explain the small size of migration flows and the presence of extensive return-migration. For example, about $20 \%$ to $50 \%$ of immigrants to the Netherlands leave this country again (CBS 2003).

Despite the knowledge that many migrations are temporary or repetitive the majority of the literature on migration (implicitly) assumes migrations are permanent. On the other hand, the literature that takes the temporal nature of migration into account by modelling the timing of departure implicitly assumes that in the end all migrants leave, see e.g. Goldstein (1964), Duleep (1994), Dustmann (1995, 2000, 2002) and Constant and Massey (2003). If migration is viewed as an investment decision to maximize human capital and/or earnings over the life-time than return and repetitive migration are not anomalies but common outcomes of a migration decision (see Dustmann (1995, 2000, 2002) and Borjas and Bratsberg (1996)). The novelty of this paper is that we use a model that allows for both permanent and temporary migration.

Human capital based theories imply that assimilation in the host country and migration decisions are correlated over time and it is therefore more appropriate to base the analysis of migration on a dynamic model that takes the timing of migration moves into account (Hill (1987) and Dustmann (2002)). Thus, the timing of the migration events, emigration or immigration, is relevant in understanding the migration. The longer the stay the more opportunities the migrant has had to learn the language and the culture of the host country. Second, along with the migration decisions other relevant characteristics of the individuals may also change over time, like the labor market status and marital status of the migrant. Third, it is hardly ever possible to observe migration decisions over the whole life time of a migrant. The knowledge that the immigrant has been in the host country from his entry time up till the end, however, contains valuable information. Duration models are very well suited to take these issues into account.

Models for duration data were initially developed in the medical sciences and reliability 
theory. Duration models or event history models have also been used extensively for demographic analysis, for example in modelling time till birth of first child, time till marriage or time till death. However, the number of analyses of migration decisions based on a duration model is rather limited and duration analysis of return migration is even more scarce. A few exceptions are Detang-Dessendre and Molho (1999), Longva (2001) and Constant and Zimmermann (2003). Most migration data lack information on the exact timing of the migration moves and only reveal whether the migrant is still in the country at the interview date. Therefore, a more common approach is to estimate a probit or logit model for the probability to return (see a.o., Reagan and Olsen (2000) and Constant and Massey (2003)). In a probit model part of the migration dynamics is discarded because only the whereabouts of the migrants at fixed points in time are considered. However, the choice of these fixed points has a big impact on the estimation results. It is also not straightforward to include time varying covariates into a probit model.

In conventional duration models it is assumed that in the end all individuals experience the event of interest. That is, all migrants are movers. This implies that eventually all immigrants leave the host country. It is, however, very plausible that some of the immigrants never leave. To account for the possibility that some of the immigrants are permanent and some are temporary we use a mover-stayer approach. This approach was developed by Boag (1949) and applied to model the recidivism of criminals (Schmidt and Witte 1989) and labor market transitions (Dunsmuir et al. 1989). ${ }^{1}$ Upon using a mover-stayer model, we can, simultaneously, identify the underlying determinants of the timing of this process and the probability to become a permanent migrant (a stayer). To our knowledge a mover-stayer approach has never been used for modelling the migration dynamics.

In light of the fact that a substantial share of the migrants that has left the country returns to The Netherlands, we also model the return from abroad using a mover-stayer model. Combining the two mover-stayer models enables us to predict the migration dynamics over the life-cycle for a given cohort of immigrants after the first arrival to The Netherlands. From the stayer probability of remaining in The Netherlands and the stayer probability of remaining abroad

\footnotetext{
${ }^{1}$ Schmidt and Witte (1989) use the term 'split-population'model. In the biomedical literature the mover-stayer model is known as the cure-model.
} 
(after some time in The Netherlands) we can deduce the long-run proportion of this cohort that ends up in The Netherlands. The intensity to leave and the intensity to return together determine the time it takes to reach this long run proportion.

The countries of Western Europe, including The Netherlands, have experienced considerable immigration flows over the past decades and have changed from emigration to immigration countries. In the last decade the majority of immigrants came to Europe for family reasons, family reunification and family formation, while in the 1960s and 1970s the migrants were mainly 'guestworkers', invited low-skilled workers. Thus the distribution over the migration motives of the immigrants has changed over the years. Most probably the migration motive is related to the migration dynamics. However, in most studies the migration motive of immigrants is unknown. Fortunately, in the data from Statistics Netherlands used in this article, information on the motive to migrate is available for recent (1995-2003) non-Dutch, non-national migrants The data further contains information on the timing of migration moves, both on the timing of immigration and on the timing of (return) emigration. This allows us to identify return and repetitive migrants and to estimate the proposed mover-stayer models. Some basic demographics characteristics of the migrants are also available. We restrict our analysis to immigrants who are in the potential labor force at the moment of entry, that is who are between 18 and 64 years of age. Younger immigrants usually migrate with their parents and older immigrants have a high probability to die before they have the possibility to leave.

The outline of the paper is as follows. In the next section we present the data and discuss the recent migration pattern to and from The Netherlands. Section 3 discusses the methodology of mover-stayers duration models. Section 4 discusses the empirical results both for the departure from the country and the return to the country. In Section 5 we use the estimation results to predict migration dynamics from and to the country over the life-cycle. Section 6 summarizes the results and states our conclusion. 


\section{Data on immigrants to The Netherlands}

In the early 1960s The Netherlands changed from an emigrant to an immigrant country. ${ }^{2}$ Im- $^{-}$ migration follows a European sequence of post World War II and post-colonial immigration, unskilled manpower recruitment and the arrival of refugees. The first period is characterized by the de-colonization of Indonesia in 1949, as a consequence many Indonesian people came to The Netherlands. In the second period, starting in the beginning of the 1960s, a large flow of 'guestworkers', mainly Turks and Moroccans arrived. The Dutch government regulated the recruitment practices by bilateral agreements with the main countries. The total inflow of immigrants reached 235,000 in 1970s. The recruitment policy stopped during the first oil crisis. However, the immigration from the recruitment countries continued as a follow-up migration, first in the form of family reunification and later also family formation. In this period the independence of Surinam also caused large immigration. Starting in the 1980s, immigration is characterized by the family reunification/formation of 'guestworkers'. Additionally, the flow of political refugees, asylum seekers has increased dramatically.

We have data on recent immigration and emigration to and from The Netherlands. Since 1995 we know for all migrants when their migration move took place. All immigration by nonDutch citizens, immigrants who do not hold the Dutch nationality, who legally entered The Netherlands is registered in the Central Register Foreigners (Centraal Register Vreemdelingen, CRV), using information from the Immigration Police (Vreemdelingen Politie) and the Immigration and Naturalization Service (Immigratie- en Naturalisatie Dienst, IND). ${ }^{3}$ The CBS, Statistics Netherlands, has linked these data to the Municipal Register of Population (Gemeentelijke Basisadministratie, GBA). These combined data contain information for all non-Dutch migrants on the timing of migration moves and on some basic demographic characteristics.

All immigrants without the Dutch nationality have to register at the Immigration Police. The people with a nationality that implies a visa to enter The Netherlands, fill in their migration

\footnotetext{
${ }^{2}$ See Zorlu and Hartog (2001) and Van Ours and Veenman (2005) for a more detailed discussion on the immigration to The Netherlands.

${ }^{3}$ The criterion for registration as an immigrant in the Netherlands is a four months time criterion. To be more precise: every person intending to stay in the Netherlands for at least two thirds of the forthcoming six months, should notify the local population register immediately after the arrival in the Netherlands.
} 
motive when they apply for the visa. There are different requirements for different visas. People with other, Western nationalities, fill in their migration motive at their mandatory registration. The migration motive is only available for those immigrants who are still registered at the end of each year, starting 1997. Thus, the main migration motive for non-Dutch immigrants is not available for those immigrants that leave, die or naturalize before January $1^{\text {st }} 1998$ or before the end of the year of arrival. With these data we can identify important groups of immigrants to the Netherlands. Statistics Netherlands make the distinction between labor-migrants, family reunification migrants, family-formation migrants, student immigrants, asylum seekers (and refugees), and immigrants for other reasons (including a.o. joining with labor migrant, medical treatment and Au Pair). Because we are interested in the migration moves of the potential labor force we restrict our analysis to non-Dutch (not holding the Dutch nationality) immigrants between 18 and 64 years of age. The distribution of those immigrants over the migration motives at first arrival to The Netherlands is depicted in Figure 1. Figure 2 shows the development of the absolute numbers of immigrants over the years 1995 till 2003. ${ }^{4}$

From 1995 till 2001 the number of immigrants increased every year. In 2001 69,000 nonDutch immigrants between 18 and 64 years of age entered The Netherlands. In the last two years the inflow of immigrants decreased to 57,000 in 2003. This decrease is most probably induced by two phenomena. First, the more strict asylum policy of the Dutch government has reduced the inflow of refugees from 15,000 in 2000 and 2001 to 5,000 in 2003. Second, the downfall of the Dutch economy has led to a reduction in the number of labor immigrants. In the last 10 years family-formation has been the most important reason to migrate to The Netherlands (26\%). Labor migrants $(23 \%)$ and refugees $(17 \%)$ are also important groups. Because the migration motive is unknown for the immigrants that leave the country in the same year they entered we have a relatively large number of immigrants with unknown migration motive.

We focus our analysis on four migration motives: labor, family reunion, family formation and study. Asylum seekers are removed from the sample because many of them are not immediately registered in the Municipal Register of Population. Most of the asylum seekers are only registered after they have received a living permission. It can take up to eight years until a living permission

\footnotetext{
${ }^{4}$ For more information on these data see Zorlu et al. (2004) and Nicolaas et al. (2004)
} 
is granted. Thus, the registered time in The Netherlands for asylum seekers is smaller than the true duration in the country. Another issue is that some asylum seekers have a temporary permit to stay, awaiting a permanent permit. If the permanent permit is not granted the asylum seeker may be expelled from the country. Then, return migration is an exogenous event which is not based on an individual decision.

The immigrants with other reasons to enter come for a plethora of reasons and therefore they comprise a very heterogeneous group. The analysis would tell little about the migration dynamics of a individual member of this group. Besides, they only amount to $7 \%$ of all immigrants. This made us decide not to include these immigrants in the analysis sample and focus on the remaining four groups of immigrants.

In Table 1 we present some descriptive statistics for the data. Family formation migrants and, of course, students are younger than other migrants. We observe substantial differences in the gender distribution of the migrants. Labor migrants are mostly men, while migrants who come for family reasons are mostly women. Not surprisingly, migrants who come for family reasons are more often married, while students are hardly ever married. The table also shows the distribution of the migrants over a selected group of countries/regions of origin. ${ }^{5}$ The main countries of origin for each migration motive are very distinct. The majority of labor migrants originates from a country in the European Union. The rest of Asia and USA/Canada are other important countries of origin of labor migrants. The EU15/EFTA region is also an important region of origin of family reunification migrants. Turkey, Morocco, the rest of Asia and the rest of Africa are other important regions these migrants and the family formation migrants originate from. Note that the relatively large number of immigrants from Surinam is not reflected in the table because many of them have the Dutch nationality and in this article we focus on the non-Dutch immigrants only.

Table 2 summarizes the dynamic aspect of migrants. The average observed duration of stay

\footnotetext{
${ }^{5}$ EU15/EFTA are countries in the European Union, except for the 2002 new members and except for Belgium, Germany, UK and France plus the member countries of EFTA: Switzerland, Norway, Iceland. Former Yugoslavia are Croatia, Serbia \& Montenegro, Macedonia and Bosnia. New EU members are the countries that joined the European Union in 2004: Cyprus, Czech Republic, Estonia, Hungary, Latvia, Lithuania, Malta, Poland, Slovenia and, Slovakia. Rest of Asia are countries in Asia not Turkey, China, Iraq, Iran or Afghanistan. Rest of Africa are all countries in Africa except Morocco. Latin America are all countries in the Americas except USA and Canada. Australasia are Australia, New Zealand and other countries in the pacific
} 
in The Netherlands is the longest for family reunification migrants and the shortest for students. Of all labor migrants and students that arrive between January 1995 and December 2003, about $45 \%$ has left the country by the end of the observation period, December $31^{\text {st }} 2003$. For migrants who came for family reasons less than $20 \%$ has left the country. A substantial share, $6 \%-14 \%$, of the migrants that have left the country returns to The Netherlands again within the time frame. Those migrants who re-immigrate are very often repetitive movers, as, for example, a third of re-immigrated labor migrants leaves the country again. These simple descriptive statistics give an under-representation of the migration dynamics, because the recent cohorts of immigrants are only followed for a very short period of time. When we only look at the immigrants arriving in 1995 in The Netherlands, we observe that almost $40 \%$ of the immigrants from that cohort have left the country within 7 years, see also Alders and Nicolaas (2003b) and Nicolaas and Sprangers (2004).

\section{A Duration Analysis of Migration Dynamics}

In a duration model the timing of a particular event (or recurrent event) is modeled. For many economic and demographic phenomena the timing of a transition from one state into another state is important, see a.o. Lancaster (1990) and van den Berg (2001). A very obvious reason to use duration models for migration dynamics is that the timing of the migration events, emigration or immigration, is relevant in understanding the migration. It is very likely that the assimilation of the migrant in the host country depends on the length of stay in that country. That will influence the decision to leave. Another reason to apply duration models is that many relevant characteristics of the migrant may change over time. In duration models it is straightforward to incorporate time-varying variables. A final reason to use duration models is that in our data on newly arriving immigrants to The Netherlands we only observe the inand outflow of migrants from January 1995 till December 2003. For the migrants still in The Netherlands in December 2003 we do not know their complete length of stay in the country. We only know their migration history up till December 2003. This still contains valuable information and duration models are perfectly fit to exploit the information of such right censored durations.

The key variables in duration analysis are the duration till the next event, the length of 
stay of the migrant in The Netherlands, and the indicator of censoring. In duration analysis the intensity, the hazard rate, is usually modelled. ${ }^{6}$ In the study of migration dynamics, the intensity gives the instantaneous probability of leaving the country at a duration $t$ months, given that the individual stayed in the country for at least $t$ months with $\lambda(t)=\frac{f(t)}{S(t)}$ where $f(t)$ is the probability density function, and $S(t)$ is the survival function. The intensity is invariant to censoring.

Comparing the four migration motives in Figure 3 we see a clear distinction in the KaplanMeier survival curves between at the one hand migrants who come for family reasons and on the other hand labor-migrants and students. The migrants who come for family reasons leave only slowly the country while the labor and student migrants do it relatively fast. Comparing the survival curves for a selection of countries of origin in Figure 4 we notice that migrants from the former 'guestworker' countries, Turkey and Morocco, leave much slower the country than migrants from Western countries. Of course, the Kaplan-Meier survival curves give only an indication of the influence of the characteristics of the migrant on the intensity to leave.

A common way to accommodate the presence of observed characteristics is to specify a proportional intensity model $\lambda(t \mid X)=\lambda_{0}(t) \exp \left(\beta^{\prime} X_{i}(t)\right)$, where $\lambda_{0}(t)$ represents the baseline intensity, that is, the duration dependence of the intensity common to all individuals. The covariates affect the intensity proportionally, see Cox (1972). The survival function for this model is $S\left(t \mid x_{i}\right)=\exp \left(-\int_{0}^{t} \lambda_{0}(s) e^{\beta^{\prime} x_{i}(s)} d s\right)$.

\subsection{Mover-stayer models}

Up to this point we have assumed that all migrants are (potential) movers. We now account for the possibility that some migrants never make a next migration move, are permanent migrants, by using a mover-stayer approach. A mover-stayer model (see Schmidt and Witte (1989)) assumes that a latent group of individuals have a zero probability to leave, the stayers. To incorporate the possibility of defective risks the survival function is redefined as

$$
S\left(t \mid x_{i}\right)=(1-p) \exp \left(-\int_{0}^{t} \lambda_{0}(s) e^{\beta^{\prime} x_{i}(s)} d s\right)+p
$$

\footnotetext{
${ }^{6}$ In the biomedical literature the accelerated failure time that models the log-duration is also often used. In these models is it more complicated to account for censoring.
} 
where $p$ is the proportion of stayers. Thus the survival function is given by the proportion of stayers (permanent migrants), who never leave the country, plus the proportion of movers (temporary migrants) multiplied by the probability to migrate after a duration of $t$ months in the country. The proportion of stayers can also depend on observed characteristics of the migrants. To guarantee that the proportion lies between zero and one we employ a logit form: $p\left(z_{i}\right)=1 /\left(1+\exp \left(\gamma^{\prime} z_{i}\right)\right)$. Note that the interpretation of the regression coefficients $\beta$ change. The coefficients are no longer equal to the elasticity of the intensity w.r.t. the covariates. In the mover-stayer model the regression coefficients give the elasticity of the conditional intensity, conditional on being a mover.

If there is interdependence of the repeated migrations due to omitted covariates or individualspecific effects, like being adventurous, the parameter estimates may be biased and/or the estimated covariance matrix provides invalid standard errors. One approach is to explicitly model the individual-specific effects using unobserved heterogeneity. In Cox survival models this kind of model is called the mixed proportional hazard model, see for example Manton et al. (1981).

We attempted to fit both Gamma and discrete mixture models with either shared or unshared, differs unobserved heterogeneity. Shared unobserved heterogeneity assumes that the heterogeneity term remains the same for each migration of one individual, while unshared unobserved heterogeneity assumes that it differs for each migration of one individual. None of these models lead to an indication of unobserved heterogeneity or change in the parameters. We therefore do not present these models. It is, however, important to point out that the presence of stayers is compatible with a discrete mixture duration model. Heckman and Walker (1987) recognize that some specifications of the latent intensity can deliver stayers. This renders the interpretation of the coefficients (and the baseline intensity) conditional on being a mover.

Note that some immigrants may move to and from the host country before they end up in a country. That is, they may become a permanent migrant (stayer) in their second or later entry to The Netherlands. 


\section{Empirical Findings}

Before estimating mover-stayer models for both the departure from and the return to The Netherlands of recent immigrants some data issues should be mentioned. Although in principle the exact date of emigration (and second and repeated immigration) is known, some migrants do not officially inform that they leave. Their departure is only registered as "administrative removal" after the authorities have assessed that the migrant has left the municipality without showing up in the files of another municipality in The Netherlands or as an emigrant. Administrative removals are included among emigration and they amount to around $40 \%$ of the emigration, see Alders and Nicolaas (2003a). It is quite possible that some migrants that are "administratively removed" remain in The Netherlands as an illegal immigrant. However, an indication that "administrative removal" is not only induced by people who try to stay illegally in the country is that many Dutch nationals also forget to register their move. Then an administrative removal implies that the migrant has left before the date the administrative removal is recorded and instead of the true duration we measure the maximum duration of stay for such a migrant. In duration models such information is called left-censored data and it can easily be dealt with. For a left-censored duration at $t$ months the contribution to the likelihood is the probability the migrant has stayed at most $t$ months. This is equal to one minus the survival probability up to $t$ months of this migrant.

Another data issue concerns the observation of the migration motive. The migration motive is unknown for immigrants that entered the country between January 1995 and December 1997 and left the country before January 1998. This implies that the sample of immigrants that came to The Netherlands in that specific period for whom we observe the migration motive is conditional on 'survival' up to January 1998. In a duration model this is called left truncation and by conditioning on 'survival' from the date of entry till January $1^{\text {st }}, 1998$ we account for this selective observation. The migration motive is also unknown for the immigrants that leave the country before the end of the year. This implies that the immigrants with known migration motive have 'survived' up till the end of the year. Again, conditioning on the time till the end of the year will correct for this selective observation. However, for immigrants that enter the country in the last year of observation, 2003 the time till the end of the year equals the observed 
duration and we cannot correct for this selection. We, therefore, exclude the immigrants that arrived in 2003 from our analysis.

We consider three models: (1) a conventional duration model without stayers; (2) a moverstayer model; (3) a mover-stayer model with interaction terms. In Model 2 and 3 the stayer probability changes with gender, marital status, age, migration motive and country of origin. In model 3 the baseline intensity differs for each migration motive and it also allows for interaction between migration motive and country of origin. The comparison between the first two models indicates the importance of permanent migration (stayers).

Many parametric functional forms exist for the baseline intensity. However, they all put heavy restrictions of the shape of the baseline intensity. A more flexible approach is to assume a piecewise constant baseline intensity. Let the intervals $I_{m}(t)=\left(t_{m-1} \leq t<t_{m}\right)$ for $m=$ $1, \ldots, M+1$ with $t_{0}=0$ and $t_{M+1}=\infty$ be the intervals on which we define the piecewise constant intensity. Then, the baseline intensity is $\lambda_{0}(t)=e^{\alpha_{0}} \cdot\left(\sum_{m=1}^{M+1} e^{\alpha_{m}} I_{m}(t)\right)$, with $\alpha_{M+1}=0$. Thus $\alpha_{0}$ determines the intensity in the last interval. The other $\alpha$ 's determine the difference in intensity at each interval compared to this last interval. The baseline intensity for a duration of $t \in\left[t_{m-1}, t_{m}\right)$ is higher than the baseline intensity to leave for a duration of $t>t_{M}$ if $\alpha_{m}>0$ and lower if $\alpha_{m}<0$.

Our main objective is to analyze the migration dynamics of recent immigrants to The Netherlands. Not only are we interested in how fast those people leave the country, if they leave, but also whether they return and how fast. For such an analysis we need to take into account both the departure-process and the return process. Both processes are modelled by a mover-stayer model. In Section 5 we combine the departure model with the return model to predict the migration dynamics.

\subsection{Departure from The Netherlands}

The mover-stayer models contain three components, the baseline intensity, the effect of characteristics of the migrant on shifting the intensity and, the stayer-probability and the effect of migrant characteristics on this probability. The results for the models are presented in five tables, Table 3 till Table 7 . The first three tables provide the parameter estimates of the intensity 
to leave and the last two tables provide the parameter estimates of the stayer-probability. We have tried a couple of different interval choices for the piecewise constant baseline intensity and decided to use ten intervals that capture the features of the baseline intensity the best. These intervals are the first 6 months and, every half a year till 5 years. We present the results of the estimated (log) alpha's in Table 3. The implied baseline intensities for model 3 are depicted in Figure 7.

The huge differences between the estimated baseline in model 1 and model 2 is due to the existence of stayers in model 2. In model 2 (and model 3) the baseline intensity is conditional on being a mover, while in model 1 the baseline intensity is averaged over stayers and movers. This leads to a higher intensity to leave, intercept is bigger, because in model 1 the stayers push the intensity down. Just as with neglecting unobserved heterogeneity, neglecting the existence of stayers leads to more negative duration dependence. The results for model 3 indicate that the duration dependence of the departure of migrants depends on the motive they entered the country. Students have the highest intensity to leave. The intensity to leave for family formation migrants start as high as for students but decreases much faster. Migrants who come to join their family have the lowest intensity to leave.

Continuing with the second piece of the model, the influence of the covariates on the intensity to leave, it is clear from Table 4 that there are major differences in the regression coefficients estimates across migration motives. The coefficients in Table 5 refer to the country of origin of the immigrant. We have used the same division of countries/regions of origin as in Table 1 with the European Union/EFTA as reference category. If for a particular migration motive only a few migrants originate from one of these regions the region is dropped from the analysis. The gender, marital status and age (centered at the average age of 30 years and divided by 10 and in a quadratic form) are also included. Female migrants (except for those that come to join their husband) and married migrants have a lower intensity to leave.

The assimilation of migrants is probably correlated with the length of stay in the country. The assimilation can accumulate over the periods in the country. However, acquiring information about the host country is costly and migrants who intend to stay only temporarily put less effort in obtaining language and cultural skills. In our data the intended length of stay of immigrants 
is not observed, but only the real time spent in the country. The time spend in the country is captured by the baseline intensity. However, migrants who come for a second time to the country have already accumulated host country specific human capital. We therefore include an indicator of repeated migration and the time the migrant has spend in The Netherlands during the previous stay in a quadratic form. This implies that 'assimilation' declines in the first months till a 'minimal' length of stay is reached, and then increases with the length of stay. Migrants who have been in the country before indeed have a lower intensity to leave.

The country of origin is a very important factor in explaining the intensity to leave. The change in impact if we allow for stayers (from model 1 to model 2) is most prominent for migrants from new EU members, Turkey, Morocco and Surinam. Allowing for stayers changes the sign of the impact these countries of origin on the intensity to leave. Migrants from new EU members, Morocco and Surinam have a much higher intensity to leave, while migrants from Belgium and Iran have a much lower intensity to leave. Important to remember is that this is conditional on being a mover and the probability to be a mover differs substantially between these countries, as can be seen in Table 8. Model 3 also includes some interactions between the migration motive and the country of origin. Notable differences within one country of origin are: migrants who come for family reasons from new EU member states have much lower intensity to leave, migrants who come to join their spouse from Turkey and Morocco also have a much lower intensity to leave.

The third component of the mover-stayer model is the stayer probability, the probability to become a permanent migrant. The logit coefficients of this probability are given in Table 6 and Table 7. The estimated coefficients in model 3 hardly differ from the estimated coefficients in model 2. The stayer probabilities implied by the parameter estimates of model 3 are shown in Table 8 . We estimate that $25 \%$ of the labor-migrants (the reference migrants) remain in the country. The migration motive is again an important factor. Migrants who come to form a family have a higher probability to stay in the country (40\%), while students have a lower probability to stay $(18 \%)$. The stayer probability also depends heavily on the country of origin of the migrant. Migrants originating from the former Yugoslavia, Turkey, China, Iraq, Iran, Afghanistan and Surinam have a substantial higher chance to remain in The Netherlands (all 
above 50\%). Migrants from the US, Canada and Australasia have a lower probability to become a permanent migrant (both below 20\%).

\subsection{Return to The Netherlands from abroad}

About $16 \%$ of the migrants arriving in 1995 in The Netherlands leave the country and return before the end of 2003. Thus, even in this relatively short period of nine years, repeated migration is an important phenomenon. For a full coverage of the migration dynamics understanding the speed of return, if they return, of migrants abroad who first spent some time in the country is imperative. In our data we only observe the migrants while officially registered in The Netherlands. Therefore, we cannot include home country characteristics, like the wage differential with the Dutch wages or unemployment level, in the model to explain the return to The Netherlands.

However, if the migrant returns we observe the exact time of this new entry to the country and we can link this with the earlier information on this migrant. If the migrant has not returned within the observation period, (s)he may stay abroad or return later. This information is rich enough to allow the estimation of mover-stayer models for returning to The Netherlands from abroad.

It is important to note that the left-truncation issues of the departure from the country are absent in the return from abroad. For a migrant that has been administratively removed the exact date (s)he left the country is unknown. This implies that the duration of stay abroad we observe is at least from the administrative removal day till re-entry to the country (or the end of the observation period). Thus, if we assume that the migrants that are administratively removed have left the country, administrative removal only induces extra right-censoring.

In Figure 5 and Figure 6 we present the Kaplan-meier survival curves for the duration abroad before returning to The Netherlands. The return form abroad occurs with a much lower pace than leaving the country, after 5 years abroad less than $80 \%$ has returned, and the differences in the Kaplan-Meier curves are much smaller, both for the migration motives and for the country of origin.

For the return of recent immigrants to The Netherlands we also estimate three models; a conventional duration model without stayers, a mover-stayer model and, a mover-stayer model 
with interaction terms. The results are presented in four tables, Tabel 9 till Table 12. The first two tables provide the parameter estimates of the intensity to return and the last two tables provide the parameter estimates of the stayer-probability (of staying abroad).

The first component of the mover-stayer model is the baseline intensity. We have tried a couple of different interval choices and decided to use four intervals that capture the features of the baseline intensity the best. These intervals are the first 6 months and, every half a year till 2 years. We present the results of the estimated $(\log )$ alpha's in Table 9 . The implied baseline intensities for model 3 are depicted in Figure 8. The differences between the estimated baseline in model 1 and model 2 is not as big as in baseline intensity of leaving the country. The only exception is the impact of the migration motive. Just as in the model for departure the baseline intensity in model 2 and 3 is conditional on being a mover, thus returning to The Netherlands. The results for model 3 indicate that the duration dependence of the return of migrants depends on the motive they entered The Netherlands. Students have the highest intensity to return. Labor-migrants have the lowest intensity to return.

The second component of the mover-stayer models is the impact of the observed migrant characteristics on the intensity to return. Again the gender, marital status and age of the migrants are important indicators of the intensity of the migration dynamics (see Table 9). In line with the assimilation theory we find that migrants who have been in The Netherlands before have a higher intensity to return. The impact of the country of origin on the intensity to return changes dramatically when we allow for the existence of stayers, thus migrants who never return to The Netherlands. Migrants originating from France, the rest of Asia, the USA/Canada and Australasia have a lower intensity to return, while migrants from Surinam have a higher intensity to return (see Table 10). Including interaction between the migration motive and the country of origin show differences in the intensity to return for migrants from one country but with different migration motives.

The third component of the mover-stayer models is the stayer-probability, probability to remain abroad. The logit coefficients of this probability are given in Table 11 and Table 12 and the implied stayer probabilities are shown in Table 13. The migration motive is again an important factor explaining the stayer probability. Migrants who come to form a family have 
a lower probability to remain abroad (23\%), while migrants who come to join their family and students have a higher probability to remain abroad ( $81 \%$ and $94 \%)$. The stayer probability also depends heavily on the country of origin of the migrant. Migrants originating from the former Yugoslavia, Turkey, China, Iran, rest of Asia, Morocco, Surinam and Australasia have a substantial lower chance to remain abroad.

\section{$5 \quad$ Predicting Lifetime Migration Dynamics}

In the previous section we have discussed the estimation of mover-stayer models for both the departure from The Netherlands and the return from abroad back into the country. Some of the migrants move back and forth, while other stay in The Netherlands or stay abroad (after some time spend in The Netherlands). Migrants that repeatedly move back and forth can, each time they enter, become a stayer. The intensity to leave determines how long the 'movers' stay in the country. After they have left the country they either become a stayer abroad or return to The Netherlands again. The intensity to return determines how long these 'movers' stay abroad. At their, possible, second entry to the country they can become a stayer or a mover. In principle this could repeat again and again.

Thus, the estimated stayer-probability to stay in The Netherlands underestimates the true proportion of migrants that end-up in the country. This proportion can be derived from the limit proportions of the implied Markov Chain of the combination of both mover-stayer models. This Markov Chain consists of with two states, the migrant is in The Netherlands or the migrant is abroad. If the probability to stay permanently in The Netherlands is denoted by $P_{i, \mathrm{NL}}$ and the probability to stay permanently abroad is denoted by $P_{i, \text { ab }}$, both conditional on the observed characteristics of the migrant available in our data, the long run probability to end-up in The Netherlands is

$$
\pi_{i, N L}=\frac{P_{i, \mathrm{NL}}}{P_{i, \mathrm{NL}}+P_{i, \mathrm{ab}}-P_{i, \mathrm{NL}} \cdot P_{i, \mathrm{ab}}} .
$$

These implied log-run probabilities are shown in Table 14 . A majority of $74 \%$ of the family formation migrants ends-up in The Netherlands. On average 51\% of the labor migrants, $35 \%$ of the family reunion migrants and $19 \%$ of the students end-up, with maybe some time abroad, in the country. Migrants from the USA/Canada and Australasia have the lowest probability to 
end-up in the country, while migrants from Iraq and Afghanistan mostly (67\% to $99 \%$ ) end-up in the country.

The importance of repeated migration can be derived directly from the stayer probabilities $P_{i, \mathrm{NL}}$ and $P_{i, \mathrm{ab}}$. In the long-run the probability to return to the country at least once is equal to $\left(1-P_{i, \mathrm{NL}}\right) \times\left(1-P_{i, \mathrm{ab}}\right)$. Consider, for example, a cohort of unmarried male labor migrants from Turkey entering The Netherlands. From this cohort $87 \%$ ends-up in the country (see Table 14). Before they settle down forever, these migrants may have gone abroad temporarily. At first entry $50 \%$ of these Turkish migrants become a stayer (see Table 8 ). The remaining $50 \%$ leave the country and $15 \%$ of them never return to the country (see Table 13 ). Thus, $43 \%=50 \% \times 85 \%$ of the original cohort eventually enters the country again. From those Turkish migrants that enter again $50 \%$ decide to stay in The Netherland, etc.

The time it takes to reach the long-run proportion depends on the intensity to leave and on the intensity to return from abroad. With the estimated stayer probabilities and the estimated intensities to leave and return we can predict, for any cohort of migrants, the migration dynamics after the first entry to The Netherlands. The prediction is based on simulation of a hypothetical cohort of immigrants using the estimated coefficients of model 3 for both leaving and returning. First, we simulate which of these migrants become a stayer in the country. Then for the movers we simulate for each month whether the migrant leaves. When a (simulated) migrant leaves we simulate whether (s)he remains abroad forever. If the migrant is prone to return we simulate the return on a monthly basis. If a (simulated) migrant returns to the country we simulate whether (s)he remains in the country, etc. We stop simulating after 25 years (300 months). We repeat 100 of such simulations and take the average percentage of the original cohort in the country at each month after entry to construct our prediction.

First we predict the migration dynamics for a typical immigrant for each of the four migration motives, see figure 9. That are, an unmarried male labor-migrant from one of the EU/EFTA countries (30 years), a married female migrant from Turkey (30 years) who joins her husband, an unmarried female from Turkey (29 years) who come to marry and, an unmarried male student from one of the EU/EFTA countries (21 years). from the figure it is clear that not only does the final percentage of the cohort that ends-up in The Netherlands differ but also the pattern to 
this long-run probability. The students and family reunion migrants reach their long-run probability relatively fast, while for the labor-migrants and family formation migrants the long-run probability has not been reached within 25 years after entry. For latter migrants the percentage of the original cohort still in the country is, after an initial drop, slowly increasing. We also predict the migration dynamics for four common types of migrants for each migration motive, depicted in Figure 10 till Figure 13. It is clear that not only the long-run probability to stay differ substantially for migrants who come for the same reason, but also the pattern to that equilibrium level.

Thus, for a complete view of the migration dynamics it is important to allow for both permanent (stayers) migrants and temporary (movers) migrants. The analysis of this section also shows that both the departure and the return should be considered for a full coverage of the migration dynamics.

\section{Conclusion}

Most previous studies treat migration as a once-and-for all event and the studies that take the return migration into account neglect the fact that a some migrants remain in the host country. For a dynamic analysis of migration from a life-cycle perspective both temporary migrants, who leave the country and who may return or who make repetitive moves, and permanent migrants, who stay forever in the host country, are important. In this paper a coherent modeling approach is developed that includes both temporary and permanent migrants.

By applying a mover-stayer model for the dynamic process of migration we can identify the underlying determinants of the timing of this process, both for the timing of departure from the host country and for the timing of the return from abroad back to the host country. It also enables us to identify the characteristics of the migrants that influence the probability to become a stayer (permanent migrant) in the host country or abroad.

Using data from Statistics Netherlands we have estimated mover-stayer models for the nonDutch immigrants (18-64 years) who arrived during 1995-2003. The data contain information on the timing of migration moves and some demographic characteristics of all migrants entering or leaving The Netherlands during this period. The main migration motive is also available 
and based on this motive we distinguish four types of migrants: labor-migrants, family reunion migrants, family-formation migrants and students.

Our results provide compelling evidence that some immigrants to The Netherlands are permanent, while other immigrants are prone to leave again. The estimation results show big differences in the stayer probability and the intensity of departure by migration motive and by country of origin of the migrant. Not surprisingly, students are the most prone to leave (and hardly return from abroad) and family formation migrants are the least prone to leave (and return very frequently from abroad). Migrants from countries that used to send guestworkers in the 60s and 70s of the previous century to The Netherlands, in particular Turkey and Morocco, stay more often permanently in the country than migrants form Western countries.

By combining the stayer probabilities for remaining in the host country and remaining abroad the long-run probability to end-up in the host country can be deduced. Some of these migrants become a stayer at their first entry in the host country, while temporary migrants leave after some time. Of those migrants that have left, some stay abroad and some return to the host country again. In the long-run the migrant ends-up in the host country or abroad. The combined models also provide a framework to predict the migration dynamics to and from The Netherlands of a particular cohort of immigrants. The intensity to leave determines how long these migrants stay in the country. The intensity to return determines how long these migrants stay abroad. The predicted life-cycle migration dynamics show that not only the long-run probability to end-up in The Netherlands is very distinct among specific immigrants, but also the pattern towards this long-run equilibrium differs among the immigrants. For some migrants we predict a fast (almost monotonic) convergence to the long-run probability, e.g. students leave fast and hardly return from abroad, and for other migrants we predict that the percentage in The Netherlands after an initial drop gradually increases due to returning immigrants (e.g. for labor migrants). Thus, for a complete view of the migration dynamics it is important to allow for both permanent (stayers) migrants and temporary (movers) migrants and that return from abroad should not be neglected.

A drawback of the used data is that it lacks information on important factors that influence migration decisions. In the future we hope to link the current data to data on socio-economic 
characteristics of immigrants. Statistics Netherlands is building a huge dynamic individual based database on social-economic variables, the SSB (Social Statistisch Bestand= Social statistical database), that can be linked to the current data and many other data at Statistics Netherlands. With the linked data it would be possible, for example, to infer how the labor-market status of migrants in The Netherlands affects their migration dynamics.

\section{References}

Alders, M. and H. Nicolaas (2003a). Administratieve correcties in de bevolkingsstatistieken (Administrative corrections in the population statistics). Bevolkingstrends 51(4), 36-42.

Alders, M. and H. Nicolaas (2003b). One in three immigrants leave within six years. $C B S$ Web Magazine, 20 January 2003.

Boag, J. W. (1949). Maximum likelihood estimation of the proportion of patients cured by cancer therapy. Journal of the Royal Statistical Society: Series B 11, 15-44.

Borjas, G. J. (1994). The economics of immigration. Journal of Economic Literature 32, $1667-1717$.

Borjas, G. J. and B. Bratsberg (1996). Who leaves? the outmigration of the foreignborn. The Review of Economics and Statistics 78, 165-176.

CBS (2003). Allochtonen in Nederland 2003. Voorburg.

Constant, A. and D. S. Massey (2003). Self-selection, earnings and out-migration: A longitudinal study of immigrants to Germany. Journal of Population Economics 16, 631-653.

Constant, A. and K. F. Zimmermann (2003). Circular movements and time away from the host country. Discussion Paper 960, IZA, Bonn.

Cox, D. R. (1972). Regression models and life-tables (with discussion). Journal of the Royal Statistical Society: Series B 34, 187-220.

Detang-Dessendre, C. and I. Molho (1999). Migration and changing employment status: A hazard function analysis. Journal of Regional Science 39, 103-123. 
Duleep, H. O. (1994). Social security and the emigration of immigrants. Social Security Bulletin $57,37-52$.

Dunsmuir, W., R. Tweedie, L. Flack, and K. Mengersen (1989). Modelling of transitions between employment states for young Australians. Australian Journal of Statistics 31A, $165-196$.

Dustmann, C. (1995). Return migration: The european experience. Economic Policy 22, $214-250$.

Dustmann, C. (2000). Temporary migration and economic assimilation. Swedish Economic Policy Review 7, 213-244.

Dustmann, C. (2002). Return migration, wage differentials, and the optimal migration duration. European Economic Review 47, 353-369.

Goldstein, S. (1964). The extend of repeated migration: An analysis based on the Danish population register. Journal of the American Statistical Association 59, 1121-1132.

Heckman, J. J. and J. R. Walker (1987). Using goodness of fit and other criteria to choose among competing duration models: A case study of Hutterite data. In C. C. Clogg (Ed.), Sociological Methodology (1987), pp. 247-308. American Sociological Association: Washington DC.

Hill, J. K. (1987). Immigrant decisions concerning durations of stay and migratory frequency. Journal of Development Economics 25, 221-234.

Lancaster, T. (1990). The Econometric Analysis of Transition Data. Cambridge University Press.

Longva, P. (2001). Out-migration of immigrants: Implications for assimilation analysis. Memorandum 04/2001, University of Oslo.

Manton, K. G., E. Stallard, and J. W. Vaupel (1981). Methods for the mortality experience of heterogeous populations. Demography 18, 389-410.

Nicolaas, H. and A. Sprangers (2004). Immigrants come and go. CBS Web Magazine, 11 October 2004. 
Nicolaas, H., A. Sprangers, A. Zorlu, and J. Hartog (2004). Migranten: Wie komen, wie gaan terug en wie laten hun gezin overkomen? (Migrants: Who comes, who returns and who will bring their family?). Bevolkingstrends 52(2), 36-42.

Reagan, P. B. and R. J. Olsen (2000). You can go home again: Evidence from longitudinal data. Demography 37, 339-350.

Roodenburg, H., R. Euwals, and H. ter Rele (2003). Immigration and the Dutch Economy. The Hague, The Netherlands: CPB Netherlands Bureau for Economic Policy.

Schmidt, P. and A. D. Witte (1989). Predicting criminal recidivism using 'split population' survival time models. Journal of Econometrics 40, 141-159.

van den Berg, G. J. (2001). Duration models: Specification, identification, and multiple duration. In J. Heckman and E. Leamer (Eds.), Handbook of Econometrics, Volume V, Chapter 55, pp. 3381-3460. Amsterdam: North-Holland.

Van Ours, J. and J. Veenman (2005). The netherlands; old emigrants - young immigrant country. In K. Zimmermann (Ed.), European Migration: What do we know?, pp. 173-196. Oxford UP.

Zorlu, A. and J. Hartog (2001). Migration and immigrants: The case of The Netherlands. Discussion paper 2001-042, Tinbergen Institute.

Zorlu, A., J. Hartog, A. Sprangers, and H. Nicolaas (2004). Retourmigratiegedrag van recente immigranten (Return migration of recent immigrants). Economische Statistische Berichten (ESB) 20 augustus 2004, 402-404. 


\section{A Tables and Figures}

Table 1: Basic statistics immigrants

\begin{tabular}{|c|c|c|c|c|}
\hline & $\overline{\text { Labour }}$ & "fam. reunification far & 1. formation & Study \\
\hline average age & 32 & 30 & 29 & 21 \\
\hline female & $30.6 \%$ & $71.2 \%$ & $69.0 \%$ & $46.6 \%$ \\
\hline married & $12.4 \%$ & $42.5 \%$ & $41.7 \%$ & $2.1 \%$ \\
\hline & & Country of origin & & \\
\hline Europe & & & & \\
\hline Belgium & $5.3 \%$ & $1.4 \%$ & $0.7 \%$ & $1.5 \%$ \\
\hline Germany & $11.3 \%$ & $3.8 \%$ & $2.1 \%$ & $8.6 \%$ \\
\hline UK & $18.0 \%$ & $3.8 \%$ & $1.2 \%$ & $1.5 \%$ \\
\hline France & $5.6 \%$ & $1.2 \%$ & $0.7 \%$ & $2.6 \%$ \\
\hline EU15/EFTA & $22.2 \%$ & $5.1 \%$ & $2.6 \%$ & $12.9 \%$ \\
\hline Former Yugo. & $0.6 \%$ & $3.8 \%$ & $2.5 \%$ & $1.3 \%$ \\
\hline new EU & $3.7 \%$ & $2.9 \%$ & $5.3 \%$ & $5.3 \%$ \\
\hline $\begin{array}{r}\text { rest of Europe } \\
\text { Asia }\end{array}$ & $4.1 \%$ & $4.8 \%$ & $5.9 \%$ & $6.3 \%$ \\
\hline Turkey & $1.8 \%$ & $12.9 \%$ & $17.6 \%$ & $1.4 \%$ \\
\hline China & $1.2 \%$ & $2.0 \%$ & $2.0 \%$ & $11.6 \%$ \\
\hline Iraq & $<0.1 \%$ & $7.3 \%$ & $0.5 \%$ & $<0.1 \%$ \\
\hline Iran & $0.3 \%$ & $2.1 \%$ & $0.8 \%$ & $0.7 \%$ \\
\hline Afghanistan & $<0.1 \%$ & $3.5 \%$ & $0.4 \%$ & $<0.1 \%$ \\
\hline $\begin{array}{l}\text { rest of Asia } \\
\text { Africa }\end{array}$ & $8.9 \%$ & $11.2 \%$ & $14.0 \%$ & $19.1 \%$ \\
\hline Morocco & $1.0 \%$ & $11.9 \%$ & $16.4 \%$ & $3.7 \%$ \\
\hline $\begin{array}{l}\text { rest of Africa } \\
\text { America }\end{array}$ & $5.1 \%$ & $10.4 \%$ & $10.0 \%$ & $11.1 \%$ \\
\hline USA/Can & $7.1 \%$ & $3.4 \%$ & $3.6 \%$ & $4.2 \%$ \\
\hline Surinam & $0.3 \%$ & $3.4 \%$ & $6.1 \%$ & $2.4 \%$ \\
\hline $\begin{array}{r}\text { Latin America } \\
\text { Australasia }\end{array}$ & $2.0 \%$ & $4.5 \%$ & $6.8 \%$ & $5.3 \%$ \\
\hline Australasia & $1.6 \%$ & $0.8 \%$ & $0.9 \%$ & $0.6 \%$ \\
\hline \# observations & 104917 & 36702 & 116100 & 40677 \\
\hline
\end{tabular}

Source: Statistics Netherlands, based on own calculations. 
Table 2: Basic duration statistics immigrants

\begin{tabular}{l|cccc}
\hline \hline & Labour & fam. reunification & fam. formation & Study \\
\cline { 2 - 5 }$\%>5$ years in NL & $20 \%$ & $45 \%$ & $39 \%$ & $16 \%$ \\
duration of stay (mos) & 35 & 58 & 45 & 29 \\
return migration & $44 \%$ & $20 \%$ & $13 \%$ & $45 \%$ \\
& \multicolumn{4}{c}{ Abroad } \\
duration of stay (mos) & 29 & 32 & 27 & 31 \\
re-immigration & $6 \%$ & $9 \%$ & $14 \%$ & $6 \%$ \\
$2^{\text {nd }}$ return migration $^{\mathrm{b}}$ & $33 \%$ & Repeated migration & $19 \%$ & $33 \%$ \\
\hline \hline
\end{tabular}

Source: Statistics Netherlands, based on own calculations.

${ }^{\text {a }}$ Percentage of those that have left the country.

${ }^{\mathrm{b}}$ Percentage of those that have left the country and have returned. 
Table 3: Parameter estimates of the baseline intensity to leave.

\begin{tabular}{|c|c|c|c|c|c|c|}
\hline \multirow{4}{*}{$\alpha_{1}(0-6) \operatorname{mos}$} & \multirow[t]{2}{*}{ model 1} & \multirow[t]{2}{*}{ model 2} & \multicolumn{4}{|c|}{ model 3} \\
\hline & & & labor & family reunion & family formation & study \\
\hline & $2.395^{* *}$ & $1.215^{* *}$ & $1.141^{* *}$ & $1.977^{* *}$ & $2.011^{* *}$ & $1.010^{* *}$ \\
\hline & $(0.039)$ & $(0.049)$ & $(0.071)$ & $(0.136)$ & $(0.086)$ & $(0.174)$ \\
\hline \multirow{2}{*}{$\alpha_{2}(6-12)$ mos. } & $2.016^{* *}$ & $0.658^{* *}$ & $0.570^{* *}$ & $1.339^{* *}$ & $1.275^{* *}$ & $0.552^{* *}$ \\
\hline & $(0.036)$ & $(0.046)$ & $(0.066)$ & $(0.118)$ & $(0.082)$ & $(0.171)$ \\
\hline \multirow[t]{2}{*}{$\alpha_{3}(12-18)$ mos. } & $1.251^{* *}$ & -0.066 & $-0.307^{* *}$ & $0.661^{* *}$ & $0.538^{* *}$ & 0.130 \\
\hline & $(0.039)$ & $(0.048)$ & $(0.068)$ & $(0.121)$ & $(0.086)$ & $(0.170)$ \\
\hline \multirow[t]{2}{*}{$\alpha_{4}(18-24)$ mos. } & $1.220^{* *}$ & -0.004 & $-0.188^{* *}$ & $0.693^{* *}$ & $0.400^{* *}$ & 0.249 \\
\hline & $(0.039)$ & $(0.047)$ & $(0.067)$ & $(0.116)$ & $(0.087)$ & $(0.167)$ \\
\hline \multirow[t]{2}{*}{$\alpha_{5}(24-30)$ mos. } & $0.964^{* *}$ & $-0.130^{* *}$ & $-0.213^{* *}$ & $0.643^{* *}$ & $0.282^{* *}$ & -0.214 \\
\hline & $(0.042)$ & $(0.048)$ & $(0.068)$ & $(0.114)$ & $(0.088)$ & $(0.169)$ \\
\hline \multirow[t]{2}{*}{$\alpha_{6}(30-36)$ mos. } & $0.860^{* *}$ & $-0.159^{* *}$ & $-0.183^{* *}$ & $0.366^{* *}$ & 0.024 & -0.095 \\
\hline & $(0.044)$ & $(0.048)$ & $(0.068)$ & $(0.119)$ & $(0.093)$ & $(0.168)$ \\
\hline \multirow[t]{2}{*}{$\alpha_{7}(36-42)$ mos. } & $0.565^{* *}$ & $-0.280^{* *}$ & $-0.220^{* *}$ & 0.171 & $-0.276 *$ & $-0.353^{*}$ \\
\hline & $(0.048)$ & $(0.053)$ & $(0.074)$ & $(0.134)$ & $(0.114)$ & $(0.179)$ \\
\hline \multirow[t]{2}{*}{$\alpha_{8}(42-48)$ mos. } & $0.476^{* *}$ & $-0.248^{* *}$ & $-0.208^{* *}$ & 0.216 & -0.172 & -0.329 \\
\hline & $(0.051)$ & $(0.056)$ & $(0.077)$ & $(0.137)$ & $(0.116)$ & $(0.185)$ \\
\hline \multirow[t]{2}{*}{$\alpha_{9}(48-54) \mathrm{mos}$} & $0.430^{* *}$ & $-0.130^{*}$ & -0.026 & 0.122 & -0.097 & -0.281 \\
\hline & $(0.054)$ & $(0.058)$ & $(0.079)$ & $(0.147)$ & $(0.120)$ & $(0.193)$ \\
\hline \multirow[t]{2}{*}{$\alpha_{10}(54-60)$ mos. } & $0.204^{* *}$ & $-0.191^{* *}$ & $-0.190^{*}$ & 0.119 & -0.095 & -0.124 \\
\hline & $(0.061)$ & $(0.064)$ & $(0.091)$ & $(0.154)$ & $(0.128)$ & $(0.199)$ \\
\hline fam. reunion & $\begin{array}{c}-0.448^{* *} \\
(0.029)\end{array}$ & $\begin{array}{l}0.097^{*} \\
(0.038)\end{array}$ & - & $\begin{array}{c}-1.310^{* *} \\
(0.180)\end{array}$ & - & - \\
\hline fam. formation & $\begin{array}{c}-0.848^{* *} \\
(0.023)\end{array}$ & $\begin{array}{l}0.161^{* *} \\
(0.033)\end{array}$ & - & - & $\begin{array}{c}-0.641^{* *} \\
(0.127)\end{array}$ & - \\
\hline \multirow[t]{2}{*}{ study } & $0.317^{* *}$ & $0.198^{* *}$ & - & - & - & $0.354^{*}$ \\
\hline & $(0.020)$ & $(0.030)$ & & & & $(0.177)$ \\
\hline intercept & $\begin{array}{c}-5.131^{* *} \\
(0.037)\end{array}$ & $\begin{array}{c}-2.871^{* *} \\
(0.054)\end{array}$ & $\begin{array}{c}-2.761^{* *} \\
(0.071)\end{array}$ & - & - & - \\
\hline
\end{tabular}

Source: Statistics Netherlands, based on own calculations.

Notes: Standard errors are shown in parentheses. ${ }^{*} p<0.05 ;{ }^{* *} p<0.01$. 
Table 4: Parameter estimates of intensity to leave

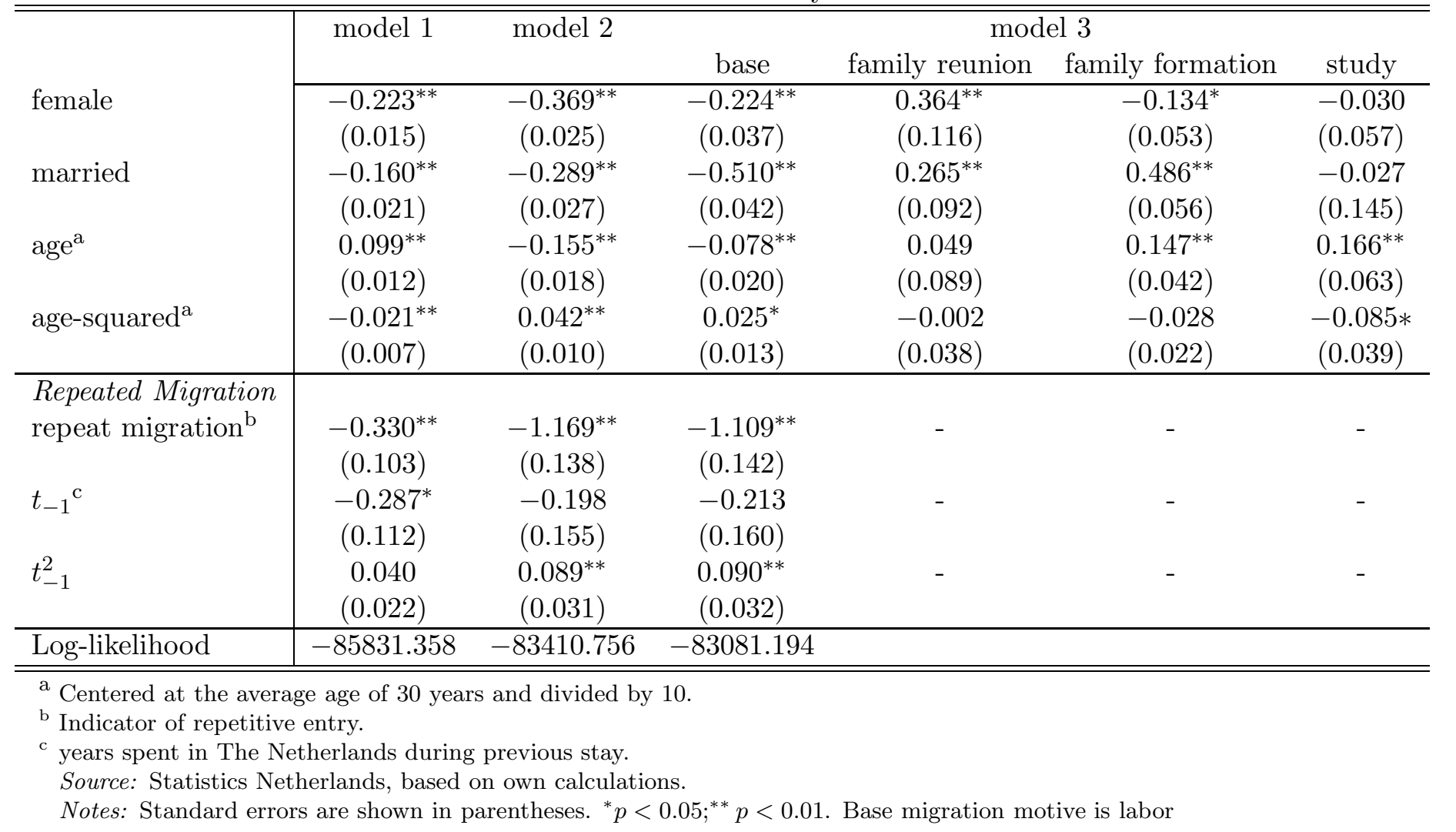


Table 5: Parameter estimates of intensity to leave, country of origin

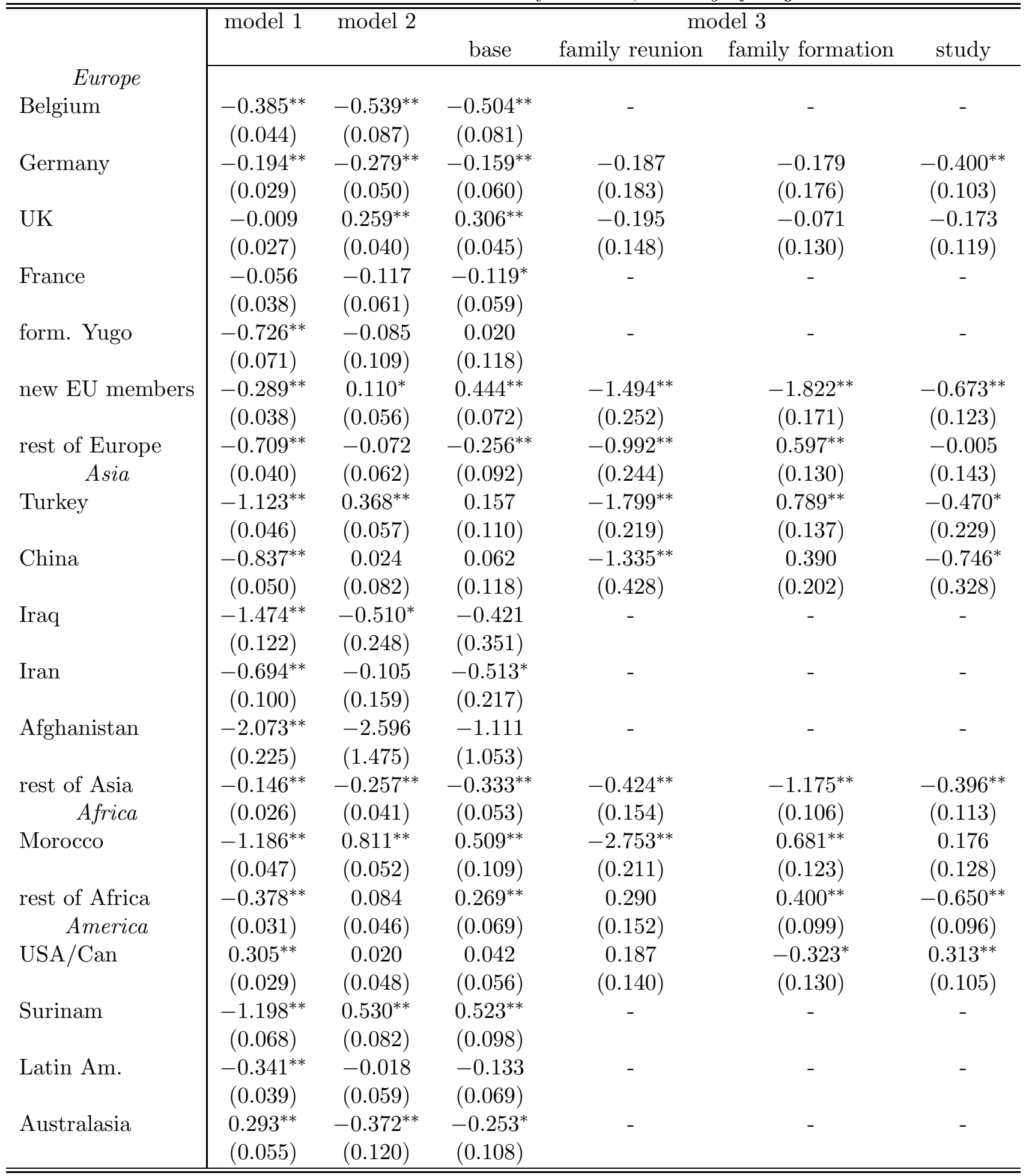

Source: Statistics Netherlands, based on own calculations.

Notes: Standard errors are shown in parentheses. ${ }^{*} p<0.05 ;^{* *} p<0.01$. Base country of origin is EU/EFTA. Base migration motive is labor 
Table 6: Parameter estimates for probability to stay

\begin{tabular}{l|cc}
\hline \hline \multirow{3}{*}{ female } & model 2 & model 3 \\
\cline { 2 - 3 } married & $0.382^{* *}$ & $0.379^{* *}$ \\
& $(0.024)$ & $(0.025)$ \\
age $^{\mathrm{a}}$ & $0.251^{* *}$ & $0.187^{* *}$ \\
& $(0.029)$ & $(0.033)$ \\
age-squared $^{\mathrm{a}}$ & $-0.133^{* *}$ & $-0.142^{* *}$ \\
& $(0.017)$ & $(0.018)$ \\
fam. reunion & $0.027^{*}$ & $0.036^{* *}$ \\
& $(0.011)$ & $(0.011)$ \\
fam. formation & $0.579^{* *}$ & $0.282^{* *}$ \\
& $(0.040)$ & $(0.064)$ \\
study & $1.055^{* *}$ & $0.682^{* *}$ \\
& $(0.032)$ & $(0.043)$ \\
& $-0.449^{* *}$ & $-0.405^{* *}$ \\
Constant & $(0.033)$ & $(0.043)$ \\
\hline \hline
\end{tabular}

${ }^{\mathrm{a}}$ Centered at the average age of 30 years and divided by 10 .

Source: Statistics Netherlands, based on own calculations.

Notes: Standard errors are shown in parentheses. ${ }^{*} p<0.05$; $^{* *} p<0.01$. 
Table 7: Parameter estimates for probability to stay, Country of origin

\begin{tabular}{|c|c|c|}
\hline \multirow[b]{2}{*}{ Europe } & \multicolumn{2}{|c|}{$\begin{array}{ll}\text { model } 2 & \text { model } 3\end{array}$} \\
\hline & & \\
\hline \multirow[t]{2}{*}{ Belgium } & $0.424^{* *}$ & $0.463^{* *}$ \\
\hline & $(0.079)$ & $(0.073)$ \\
\hline \multirow[t]{2}{*}{ Germany } & $0.242^{* *}$ & $0.276^{* *}$ \\
\hline & $(0.048)$ & $(0.046)$ \\
\hline \multirow[t]{2}{*}{ UK } & -0.059 & -0.084 \\
\hline & $(0.045)$ & $(0.046)$ \\
\hline \multirow[t]{2}{*}{ France } & 0.060 & 0.064 \\
\hline & $(0.061)$ & $(0.060)$ \\
\hline \multirow[t]{2}{*}{ form. Yugo } & $0.955^{* *}$ & $1.104^{* *}$ \\
\hline & $(0.093)$ & $(0.093)$ \\
\hline \multirow[t]{2}{*}{ new EU members } & $0.457^{* *}$ & $0.231^{* *}$ \\
\hline & $(0.056)$ & $(0.077)$ \\
\hline rest of Europe & $0.957^{* *}$ & $0.921^{* *}$ \\
\hline Asia & $(0.055)$ & $(0.060)$ \\
\hline \multirow{2}{*}{ Turkey } & $1.152^{* *}$ & $1.068^{* *}$ \\
\hline & $(0.066)$ & $(0.075)$ \\
\hline \multirow[t]{2}{*}{ China } & $1.236^{* *}$ & $1.168^{* *}$ \\
\hline & $(0.069)$ & $(0.116)$ \\
\hline \multirow[t]{2}{*}{ Iraq } & $1.717^{* *}$ & $1.905^{* *}$ \\
\hline & $(0.139)$ & $(0.172)$ \\
\hline \multirow[t]{2}{*}{ Iran } & $0.983^{* *}$ & $1.056^{* *}$ \\
\hline & $(0.130)$ & $(0.149)$ \\
\hline \multirow[t]{2}{*}{ Afghanistan } & 0.793 & $2.203^{* *}$ \\
\hline & $(1.976)$ & $(0.781)$ \\
\hline rest of Asia & $0.226^{* *}$ & -0.121 \\
\hline Africa & $(0.040)$ & $(0.073)$ \\
\hline \multirow[t]{2}{*}{ Morocco } & $0.802^{* *}$ & $0.529^{* *}$ \\
\hline & $(0.076)$ & $(0.088)$ \\
\hline rest of Africa & $0.509^{* *}$ & $0.481^{* *}$ \\
\hline America & $(0.047)$ & $(0.051)$ \\
\hline \multirow[t]{2}{*}{ USA/Can } & $-0.583^{* *}$ & $-0.533^{* *}$ \\
\hline & $(0.052)$ & $(0.054)$ \\
\hline \multirow[t]{2}{*}{ Surinam } & $1.062^{* *}$ & $1.322^{* *}$ \\
\hline & $(0.101)$ & $(0.106)$ \\
\hline \multirow[t]{2}{*}{ Latin Am. } & $0.477^{* *}$ & $0.636^{* *}$ \\
\hline & $(0.055)$ & $(0.055)$ \\
\hline \multirow[t]{2}{*}{ Australasia } & $-0.801^{* *}$ & $-0.590^{* *}$ \\
\hline & $(0.160)$ & $(0.125)$ \\
\hline
\end{tabular}

Source: Statistics Netherlands, based on own calculations.

Notes: Standard errors are shown in parentheses. ${ }^{*} p<0.05 ;^{* *} p<0.01$. 
Table 8: Implied stayer probabilities in The Netherlands

\begin{tabular}{l|cccc}
\hline \hline \multirow{2}{*}{ base } & labor & family reunion & family formation & study \\
\cline { 2 - 5 } & $25 \%$ & $31 \%$ & $40 \%$ & $18 \%$ \\
\hline female & $33 \%$ & $40 \%$ & $49 \%$ & $25 \%$ \\
married & $29 \%$ & $35 \%$ & $45 \%$ & $21 \%$ \\
\hline Country of origin & & & & \\
Belgium & $35 \%$ & $42 \%$ & $51 \%$ & $26 \%$ \\
Germany & $31 \%$ & $37 \%$ & $47 \%$ & $23 \%$ \\
UK & $24 \%$ & $29 \%$ & $38 \%$ & $17 \%$ \\
France & $26 \%$ & $32 \%$ & $42 \%$ & $19 \%$ \\
form. Yugo & $50 \%$ & $57 \%$ & $67 \%$ & $40 \%$ \\
new EU members & $30 \%$ & $36 \%$ & $46 \%$ & $22 \%$ \\
rest of Europe & $46 \%$ & $53 \%$ & $63 \%$ & $36 \%$ \\
Turkey & $50 \%$ & $57 \%$ & $66 \%$ & $40 \%$ \\
China & $52 \%$ & $59 \%$ & $68 \%$ & $42 \%$ \\
Iraq & $69 \%$ & $75 \%$ & $82 \%$ & $60 \%$ \\
Iran & $49 \%$ & $56 \%$ & $66 \%$ & $39 \%$ \\
Afghanistan & $75 \%$ & $80 \%$ & $86 \%$ & $67 \%$ \\
rest of Asia & $23 \%$ & $28 \%$ & $37 \%$ & $17 \%$ \\
Morocco & $36 \%$ & $43 \%$ & $53 \%$ & $28 \%$ \\
rest of Africa & $35 \%$ & $42 \%$ & $52 \%$ & $27 \%$ \\
USA/Canada & $17 \%$ & $21 \%$ & $28 \%$ & $12 \%$ \\
Surinam & $56 \%$ & $63 \%$ & $71 \%$ & $46 \%$ \\
Latin Am. & $39 \%$ & $46 \%$ & $56 \%$ & $30 \%$ \\
Australasia & $16 \%$ & $20 \%$ & $27 \%$ & $11 \%$ \\
\hline \hline
\end{tabular}

Source: Statistics Netherlands, based on own calculations.

Notes: The base migrant is an unmarried male from a country in the EU15 or EFTA (excl. Belgium, Germany, UK and France). 
Table 9: Parameter estimates of intensity to return to The Netherlands

\begin{tabular}{|c|c|c|c|c|c|c|}
\hline \multirow{3}{*}{$\alpha_{1}(0-6)$ mos. } & \multirow[t]{2}{*}{ model 1} & \multirow[t]{2}{*}{ model 2} & \multicolumn{4}{|c|}{ model 3} \\
\hline & & & labor & family reunion & family formation & study \\
\hline & $\begin{array}{l}1.069^{* *} \\
(0.033)\end{array}$ & $\begin{array}{l}0.913^{* *} \\
(0.041)\end{array}$ & $\begin{array}{l}0.813^{* *} \\
(0.054)\end{array}$ & $\begin{array}{l}1.035^{* *} \\
(0.119)\end{array}$ & $\begin{array}{l}1.086^{* *} \\
(0.070)\end{array}$ & $\begin{array}{l}0.636^{* *} \\
(0.130)\end{array}$ \\
\hline$\alpha_{2}(6-12)$ mos. & $\begin{array}{l}0.839^{* *} \\
(0.036)\end{array}$ & $\begin{array}{l}0.719^{* *} \\
(0.041)\end{array}$ & $\begin{array}{l}0.683^{* *} \\
(0.057)\end{array}$ & $\begin{array}{l}0.879^{* *} \\
(0.120)\end{array}$ & $\begin{array}{l}0.868^{* *} \\
(0.072)\end{array}$ & $\begin{array}{l}0.374^{* *} \\
(0.124)\end{array}$ \\
\hline$\alpha_{3}(12-18)$ mos. & $\begin{array}{l}0.581^{* *} \\
(0.041)\end{array}$ & $\begin{array}{l}0.487^{* *} \\
(0.043)\end{array}$ & $\begin{array}{l}0.516^{* *} \\
(0.061)\end{array}$ & $\begin{array}{l}0.579^{* *} \\
(0.131)\end{array}$ & $\begin{array}{l}0.543^{* *} \\
(0.080)\end{array}$ & $\begin{array}{c}0.190 \\
(0.126)\end{array}$ \\
\hline$\alpha_{4}(18-24)$ mos. & $\begin{array}{l}0.440^{* *} \\
(0.045)\end{array}$ & $\begin{array}{l}0.371^{* *} \\
(0.047)\end{array}$ & $\begin{array}{l}0.388^{* *} \\
(0.068)\end{array}$ & $\begin{array}{c}0.362^{*} \\
(0.146)\end{array}$ & $\begin{array}{l}0.405^{* *} \\
(0.087)\end{array}$ & $\begin{array}{c}0.224 \\
(0.125)\end{array}$ \\
\hline intercept & $\begin{array}{c}-5.817^{* *} \\
(0.048)\end{array}$ & $\begin{array}{c}-5.106^{* *} \\
(0.195)\end{array}$ & $\begin{array}{c}-5.192^{* *} \\
(0.211)\end{array}$ & - & - & - \\
\hline fam. reunion & $\begin{array}{l}0.264^{* *} \\
(0.046)\end{array}$ & $\begin{array}{l}1.039^{* *} \\
(0.146)\end{array}$ & - & $\begin{array}{l}1.480^{* *} \\
(0.266)\end{array}$ & - & - \\
\hline fam. formation & $\begin{array}{l}0.522^{* *} \\
(0.036)\end{array}$ & $\begin{array}{l}0.836^{* *} \\
(0.087)\end{array}$ & - & - & $\begin{array}{c}0.386^{*} \\
(0.160)\end{array}$ & - \\
\hline study & $\begin{array}{c}-0.325^{* *} \\
(0.038)\end{array}$ & $\begin{array}{l}1.455^{* *} \\
(0.152)\end{array}$ & - & - & - & $\begin{array}{l}2.123^{* *} \\
(0.251)\end{array}$ \\
\hline \multirow[b]{2}{*}{ female } & & & base & family reunion & family formation & study \\
\hline & $\begin{array}{c}0.011 \\
(0.027)\end{array}$ & $\begin{array}{l}-0.092 \\
(0.056)\end{array}$ & $\begin{array}{l}-0.011 \\
(0.076)\end{array}$ & $\begin{array}{c}-0.851^{* *} \\
(0.153)\end{array}$ & $\begin{array}{c}-0.181^{*} \\
(0.081)\end{array}$ & $\begin{array}{c}-0.633^{* *} \\
(0.176)\end{array}$ \\
\hline married & $\begin{array}{l}0.414^{* *} \\
(0.032)\end{array}$ & $\begin{array}{c}0.113 \\
(0.095)\end{array}$ & $\begin{array}{l}0.253^{* *} \\
(0.084)\end{array}$ & - & - & - \\
\hline $\operatorname{age}^{a}$ & $\begin{array}{c}-0.283^{* *} \\
(0.019)\end{array}$ & $\begin{array}{c}-0.258^{* *} \\
(0.034)\end{array}$ & $\begin{array}{c}-0.254^{* *} \\
(0.027)\end{array}$ & - & - & - \\
\hline age-squared $^{\mathrm{a}}$ & $\begin{array}{l}0.071^{* *} \\
(0.012)\end{array}$ & $\begin{array}{l}0.076^{* *} \\
(0.023) \\
\end{array}$ & $\begin{array}{l}0.067^{* *} \\
(0.017) \\
\end{array}$ & - & - & - \\
\hline $\begin{array}{l}\text { Repeated Migration } \\
\text { repeat migration }\end{array}$ & $\begin{array}{c}0.162^{*} \\
(0.069)\end{array}$ & $\begin{array}{l}0.310^{* *} \\
(0.077)\end{array}$ & $\begin{array}{l}0.295^{* *} \\
(0.074)\end{array}$ & - & - & - \\
\hline \multirow{2}{*}{$\begin{array}{l}t_{-1}^{\mathrm{c}} \\
t_{-1}^{2}\end{array}$} & $\begin{array}{c}-0.751^{* *} \\
(0.027)\end{array}$ & $\begin{array}{c}-0.804^{* *} \\
(0.028)\end{array}$ & $\begin{array}{c}-0.797^{* *} \\
(0.028)\end{array}$ & - & - & - \\
\hline & $\begin{array}{l}0.079^{* *} \\
(0.005)\end{array}$ & $\begin{array}{l}0.085^{* *} \\
(0.005)\end{array}$ & $\begin{array}{l}0.083^{* *} \\
(0.005)\end{array}$ & - & - & - \\
\hline Log-likelihood & -45287.21 & -45145.03 & -45055.75 & & & \\
\hline
\end{tabular}


Table 10: Parameter estimates of intensity to return to The Netherlands, country of origin

\begin{tabular}{|c|c|c|c|c|c|c|}
\hline \multirow{3}{*}{ Europe } & \multirow[t]{2}{*}{ "model 1} & \multirow[t]{2}{*}{ "model 2} & \multicolumn{4}{|c|}{ "model 3} \\
\hline & & & base & family reunion & family formation & study \\
\hline & & & & & & \\
\hline Belgium & $\begin{array}{l}0.162^{*} \\
(0.074)\end{array}$ & $\begin{array}{c}0.031 \\
(0.134)\end{array}$ & $\begin{array}{c}0.037 \\
(0.110)\end{array}$ & - & - & - \\
\hline Germany & $\begin{array}{l}0.125^{*} \\
(0.052)\end{array}$ & $\begin{array}{c}-0.213^{*} \\
(0.108)\end{array}$ & $\begin{array}{l}-0.128 \\
(0.094)\end{array}$ & - & - & - \\
\hline UK & $\begin{array}{l}-0.023 \\
(0.051)\end{array}$ & $\begin{array}{l}-0.106 \\
(0.115)\end{array}$ & $\begin{array}{l}-0.252 \\
(0.134)\end{array}$ & $\begin{array}{c}-0.814^{* *} \\
(0.271)\end{array}$ & $\begin{array}{c}-0.445^{*} \\
(0.208)\end{array}$ & $\begin{array}{l}-0.775 \\
(0.540)\end{array}$ \\
\hline France & $\begin{array}{c}-0.194^{*} \\
(0.078)\end{array}$ & $\begin{array}{c}-0.357^{*} \\
(0.143)\end{array}$ & $\begin{array}{c}-0.323^{* *} \\
(0.121)\end{array}$ & - & - & - \\
\hline form. Yugo & $\begin{array}{l}0.372^{* *} \\
(0.105)\end{array}$ & $\begin{array}{l}-0.142 \\
(0.191)\end{array}$ & $\begin{array}{c}0.093 \\
(0.155)\end{array}$ & - & - & - \\
\hline new EU members & $\begin{array}{l}0.436^{* *} \\
(0.057)\end{array}$ & $\begin{array}{c}0.136 \\
(0.111)\end{array}$ & $\begin{array}{c}0.029 \\
(0.118)\end{array}$ & $\begin{array}{c}0.083 \\
(0.270)\end{array}$ & $\begin{array}{l}0.566^{* *} \\
(0.124)\end{array}$ & $\begin{array}{c}0.012 \\
(0.258)\end{array}$ \\
\hline $\begin{array}{c}\text { rest of Europe } \\
\text { Asia }\end{array}$ & $\begin{array}{l}0.475^{* *} \\
(0.061)\end{array}$ & $\begin{array}{c}0.036 \\
(0.121)\end{array}$ & $\begin{array}{c}0.205 \\
(0.106)\end{array}$ & - & - & - \\
\hline Turkey & $\begin{array}{c}0.112 \\
(0.070)\end{array}$ & $\begin{array}{c}-0.471^{* *} \\
(0.145)\end{array}$ & $\begin{array}{l}-0.173 \\
(0.132)\end{array}$ & - & - & - \\
\hline China & $\begin{array}{l}0.275^{* *} \\
(0.092)\end{array}$ & $\begin{array}{c}-0.235 \\
(0.186)\end{array}$ & $\begin{array}{c}-0.256 \\
(0.223)\end{array}$ & $\begin{array}{l}-0.147 \\
(0.401)\end{array}$ & $\begin{array}{c}0.571^{*} \\
(0.275)\end{array}$ & $\begin{array}{c}0.553 \\
(0.343)\end{array}$ \\
\hline Iraq & $\begin{array}{c}0.003 \\
(0.222)\end{array}$ & $\begin{array}{c}-0.719^{*} \\
(0.362)\end{array}$ & $\begin{array}{l}-0.631 \\
(0.351)\end{array}$ & - & - & - \\
\hline Iran & $\begin{array}{c}0.279 \\
(0.178)\end{array}$ & $\begin{array}{l}-0.238 \\
(0.281)\end{array}$ & $\begin{array}{l}-0.167 \\
(0.249)\end{array}$ & - & - & - \\
\hline Afghanistan & $\begin{array}{c}0.366 \\
(0.356)\end{array}$ & $\begin{array}{c}0.415 \\
(0.859)\end{array}$ & $\begin{array}{c}0.562 \\
(0.602)\end{array}$ & - & - & - \\
\hline $\begin{array}{r}\text { rest of Asia } \\
\text { Africa }\end{array}$ & $\begin{array}{c}0.051 \\
(0.047)\end{array}$ & $\begin{array}{c}-0.474^{* *} \\
(0.121)\end{array}$ & $\begin{array}{c}-0.556^{* *} \\
(0.115)\end{array}$ & $\begin{array}{c}0.067 \\
(0.154)\end{array}$ & $\begin{array}{l}0.635^{* *} \\
(0.105)\end{array}$ & $\begin{array}{l}0.563^{* *} \\
(0.178)\end{array}$ \\
\hline Morocco & $\begin{array}{l}0.321^{* *} \\
(0.066)\end{array}$ & $\begin{array}{l}-0.232 \\
(0.130)\end{array}$ & $\begin{array}{c}0.007 \\
(0.122)\end{array}$ & - & - & - \\
\hline $\begin{array}{r}\text { rest of Africa } \\
\text { America }\end{array}$ & $\begin{array}{l}0.204^{* *} \\
(0.053)\end{array}$ & $\begin{array}{l}-0.121 \\
(0.109)\end{array}$ & $\begin{array}{l}-0.019 \\
(0.090)\end{array}$ & - & - & - \\
\hline USA/Can & $\begin{array}{c}-0.470^{* *} \\
(0.064)\end{array}$ & $\begin{array}{c}-0.812^{* *} \\
(0.130)\end{array}$ & $\begin{array}{c}-0.676^{* *} \\
(0.111)\end{array}$ & - & - & - \\
\hline Surinam & $\begin{array}{l}0.660^{* *} \\
(0.082)\end{array}$ & $\begin{array}{c}0.146 \\
(0.177)\end{array}$ & $\begin{array}{l}0.397^{* *} \\
(0.122)\end{array}$ & - & - & - \\
\hline Latin Am. & $\begin{array}{l}0.377^{* *} \\
(0.060)\end{array}$ & $\begin{array}{c}0.021 \\
(0.120)\end{array}$ & $\begin{array}{l}0.215^{*} \\
(0.092)\end{array}$ & - & - & - \\
\hline Australasia & $\begin{array}{c}-0.307^{* *} \\
(0.113) \\
\end{array}$ & $\begin{array}{c}-0.809^{* *} \\
(0.215) \\
\end{array}$ & $\begin{array}{c}-0.555^{* *} \\
(0.185)\end{array}$ & - & - & - \\
\hline
\end{tabular}

Source: Statistics Netherlands, based on own calculations.

Notes: Standard errors are shown in parentheses. ${ }^{*} p<0.05 ;{ }^{* *} p<0.01$. Base country of origin is EU/EFTA. Base migration motive is labor 
Table 11: Parameter estimates for probability to stay abroad

\begin{tabular}{l|cc}
\hline \hline \multirow{3}{*}{ female } & model 2 & model 3 \\
\cline { 2 - 3 } married & -0.208 & $-0.689^{* *}$ \\
& $(0.110)$ & $(0.172)$ \\
age $^{\mathrm{a}}$ & $-1.281^{* *}$ & $-1.038^{* *}$ \\
& $(0.264)$ & $(0.186)$ \\
age-squared $^{\mathrm{a}}$ & $0.162^{*}$ & $0.205^{* *}$ \\
& $(0.073)$ & $(0.062)$ \\
fam. reunion & -0.017 & -0.049 \\
& $(0.059)$ & $(0.048)$ \\
fam. formation & $2.025^{* *}$ & $2.205^{* *}$ \\
& $(0.445)$ & $(0.605)$ \\
study & $0.787^{*}$ & -0.464 \\
& $(0.340)$ & $(0.999)$ \\
& $3.091^{* *}$ & $3.456^{* *}$ \\
Constant & $(0.487)$ & $(0.629)$ \\
\hline \hline
\end{tabular}

${ }^{\mathrm{a}}$ Centered at the average age of 30 years and divided by 10 .

Source:Statistics Netherlands, based on own calculations.

Notes: Standard errors are shown in parentheses. ${ }^{*} p<0.05 ;^{* *} p<0.01$. 
Table 12: Parameter estimates for probability to stay abroad, Country of origin

\begin{tabular}{|c|c|c|}
\hline \multirow{2}{*}{ Europe } & \multicolumn{2}{|l|}{ model 2} \\
\hline & & \\
\hline \multirow[t]{2}{*}{ Belgium } & -0.255 & -0.281 \\
\hline & $(0.291)$ & $(0.266)$ \\
\hline \multirow[t]{2}{*}{ Germany } & $-0.811^{* *}$ & $-0.689^{* *}$ \\
\hline & $(0.182)$ & $(0.165)$ \\
\hline \multirow[t]{2}{*}{ UK } & -0.028 & -1.218 \\
\hline & $(0.271)$ & $(0.631)$ \\
\hline \multirow[t]{2}{*}{ France } & -0.310 & -0.259 \\
\hline & $(0.302)$ & $(0.272)$ \\
\hline \multirow[t]{2}{*}{ form. Yugo } & $-1.287^{* *}$ & $-0.915^{* *}$ \\
\hline & $(0.392)$ & $(0.309)$ \\
\hline \multirow[t]{2}{*}{ new EU members } & $-0.749^{* *}$ & $-0.606^{*}$ \\
\hline & $(0.184)$ & $(0.248)$ \\
\hline \multirow{2}{*}{$\begin{array}{c}\text { rest of Europe } \\
\text { Asia }\end{array}$} & $-1.128^{* *}$ & $-0.931^{* *}$ \\
\hline & $(0.210)$ & $(0.184)$ \\
\hline \multirow[t]{2}{*}{ Turkey } & $-1.671^{* *}$ & $-1.002^{* *}$ \\
\hline & $(0.338)$ & $(0.292)$ \\
\hline \multirow[t]{2}{*}{ China } & $-1.041^{* *}$ & $-0.566^{*}$ \\
\hline & $(0.278)$ & $(0.287)$ \\
\hline \multirow[t]{2}{*}{ Iraq } & -1.949 & -1.691 \\
\hline & $(1.168)$ & $(0.959)$ \\
\hline \multirow[t]{2}{*}{ Iran } & $-1.281^{*}$ & $-1.304^{* *}$ \\
\hline & $(0.545)$ & $(0.449)$ \\
\hline \multirow[t]{2}{*}{ Afghanistan } & 0.080 & 0.423 \\
\hline & $(1.314)$ & $(0.927)$ \\
\hline rest of Asia & $-1.236^{* *}$ & $-0.791^{* *}$ \\
\hline Africa & $(0.177)$ & $(0.175)$ \\
\hline \multirow[t]{2}{*}{ Morocco } & $-1.513^{* *}$ & $-1.291^{* *}$ \\
\hline & $(0.275)$ & $(0.211)$ \\
\hline rest of Africa & $-0.753^{* *}$ & $-0.646^{* *}$ \\
\hline America & $(0.173)$ & $(0.153)$ \\
\hline \multirow[t]{2}{*}{ USA/Can } & $-0.757^{* *}$ & $-0.537^{*}$ \\
\hline & $(0.259)$ & $(0.238)$ \\
\hline \multirow[t]{2}{*}{ Surinam } & $-1.366^{* *}$ & $-1.057^{* *}$ \\
\hline & $(0.473)$ & $(0.355)$ \\
\hline \multirow[t]{2}{*}{ Latin Am. } & $-0.848^{* *}$ & $-0.591^{* *}$ \\
\hline & $(0.208)$ & $(0.185)$ \\
\hline \multirow[t]{2}{*}{ Australasia } & $-1.289^{*}$ & -0.708 \\
\hline & $(0.577)$ & $(0.517)$ \\
\hline
\end{tabular}

Source: Statistics Netherlands, based on own calculations.

Notes: Standard errors are shown in parentheses. $* p<0.05 ; * * p<0.01$. 
Table 13: Implied stayer probabilities abroad.

\begin{tabular}{l|cccc}
\hline \hline \multirow{2}{*}{ base } & labor & family reunion & family formation & study \\
\cline { 2 - 5 } & $32 \%$ & $81 \%$ & $23 \%$ & $94 \%$ \\
\hline female & & & & \\
married & $19 \%$ & $69 \%$ & $13 \%$ & $88 \%$ \\
\hline Country of origin & & & $10 \%$ & $84 \%$ \\
Belgium & $27 \%$ & $77 \%$ & $19 \%$ & $92 \%$ \\
Germany & $19 \%$ & $69 \%$ & $13 \%$ & $88 \%$ \\
UK & $12 \%$ & $56 \%$ & $8 \%$ & $82 \%$ \\
France & $27 \%$ & $77 \%$ & $19 \%$ & $92 \%$ \\
form. Yugo & $16 \%$ & $64 \%$ & $11 \%$ & $86 \%$ \\
new EU members & $21 \%$ & $70 \%$ & $14 \%$ & $89 \%$ \\
rest of Europe & $16 \%$ & $63 \%$ & $11 \%$ & $86 \%$ \\
Turkey & $15 \%$ & $62 \%$ & $10 \%$ & $85 \%$ \\
China & $21 \%$ & $71 \%$ & $15 \%$ & $90 \%$ \\
Iraq & $8 \%$ & $45 \%$ & $5 \%$ & $74 \%$ \\
Iran & $12 \%$ & $54 \%$ & $8 \%$ & $81 \%$ \\
Afghanistan & $42 \%$ & $87 \%$ & $32 \%$ & $96 \%$ \\
rest of Asia & $18 \%$ & $66 \%$ & $12 \%$ & $87 \%$ \\
Morocco & $12 \%$ & $55 \%$ & $8 \%$ & $81 \%$ \\
rest of Africa & $20 \%$ & $70 \%$ & $14 \%$ & $89 \%$ \\
USA/Canada & $22 \%$ & $72 \%$ & $15 \%$ & $90 \%$ \\
Surinam & $14 \%$ & $60 \%$ & $10 \%$ & $84 \%$ \\
Latin Am. & $21 \%$ & $71 \%$ & $14 \%$ & $89 \%$ \\
Australasia & $19 \%$ & $68 \%$ & $13 \%$ & $88 \%$ \\
\hline \hline
\end{tabular}

Source: Statistics Netherlands, based on own calculations.

Notes: The base migrant is an unmarried male from a country in the EU15 or EFTA (excl. Belgium, Germany, UK and France). 
Table 14: Long-run probability to reside in The Netherlands

\begin{tabular}{l|cccc}
\hline \hline \multirow{2}{*}{ base } & labor & family reunion & family formation & study \\
\cline { 2 - 5 } & $51 \%$ & $35 \%$ & $74 \%$ & $19 \%$ \\
\hline female & $72 \%$ & $49 \%$ & $88 \%$ & $27 \%$ \\
married & $74 \%$ & $47 \%$ & $89 \%$ & $24 \%$ \\
\hline Country of origin & & & & \\
Belgium & $67 \%$ & $48 \%$ & $85 \%$ & $28 \%$ \\
Germany & $70 \%$ & $46 \%$ & $87 \%$ & $25 \%$ \\
UK & $71 \%$ & $42 \%$ & $88 \%$ & $20 \%$ \\
France & $57 \%$ & $38 \%$ & $79 \%$ & $21 \%$ \\
form. Yugo & $86 \%$ & $68 \%$ & $95 \%$ & $44 \%$ \\
new EU members & $67 \%$ & $44 \%$ & $86 \%$ & $24 \%$ \\
rest of Europe & $84 \%$ & $64 \%$ & $94 \%$ & $40 \%$ \\
Turkey & $87 \%$ & $68 \%$ & $95 \%$ & $44 \%$ \\
China & $84 \%$ & $67 \%$ & $94 \%$ & $45 \%$ \\
Iraq & $97 \%$ & $87 \%$ & $99 \%$ & $67 \%$ \\
Iran & $89 \%$ & $70 \%$ & $96 \%$ & $45 \%$ \\
Afghanistan & $88 \%$ & $82 \%$ & $95 \%$ & $68 \%$ \\
rest of Asia & $63 \%$ & $37 \%$ & $83 \%$ & $19 \%$ \\
Morocco & $83 \%$ & $58 \%$ & $94 \%$ & $32 \%$ \\
rest of Africa & $73 \%$ & $51 \%$ & $89 \%$ & $29 \%$ \\
USA/Canada & $47 \%$ & $27 \%$ & $72 \%$ & $13 \%$ \\
Surinam & $90 \%$ & $74 \%$ & $96 \%$ & $50 \%$ \\
Latin Am. & $75 \%$ & $54 \%$ & $90 \%$ & $32 \%$ \\
Australasia & $49 \%$ & $27 \%$ & $74 \%$ & $12 \%$ \\
\hline \hline
\end{tabular}

Source: Statistics Netherlands, based on own calculations.

Notes: The base migrant is an unmarried male from a country in the EU15 or EFTA (excl. Belgium, Germany, UK and France). 


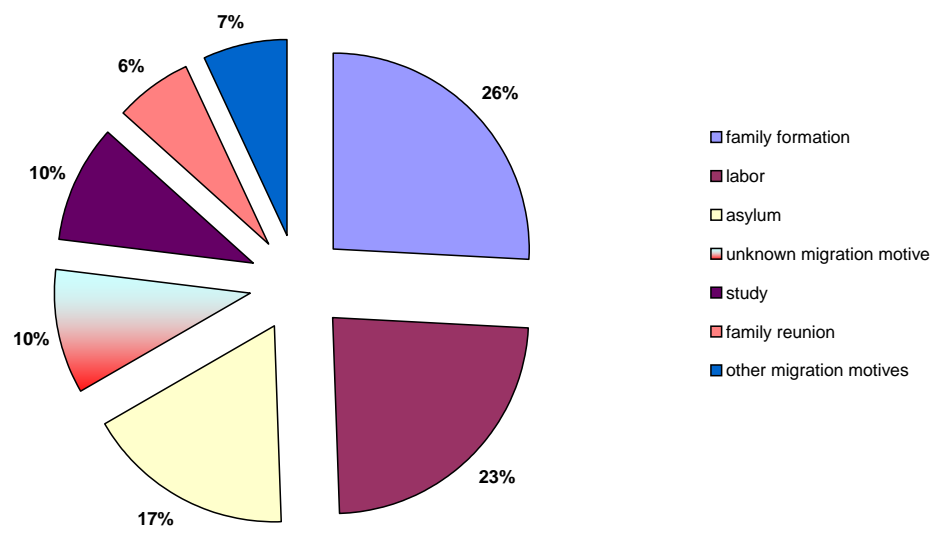

Figure 1: Non-Dutch immigrants (18-64) by migration motive, 1995-2003

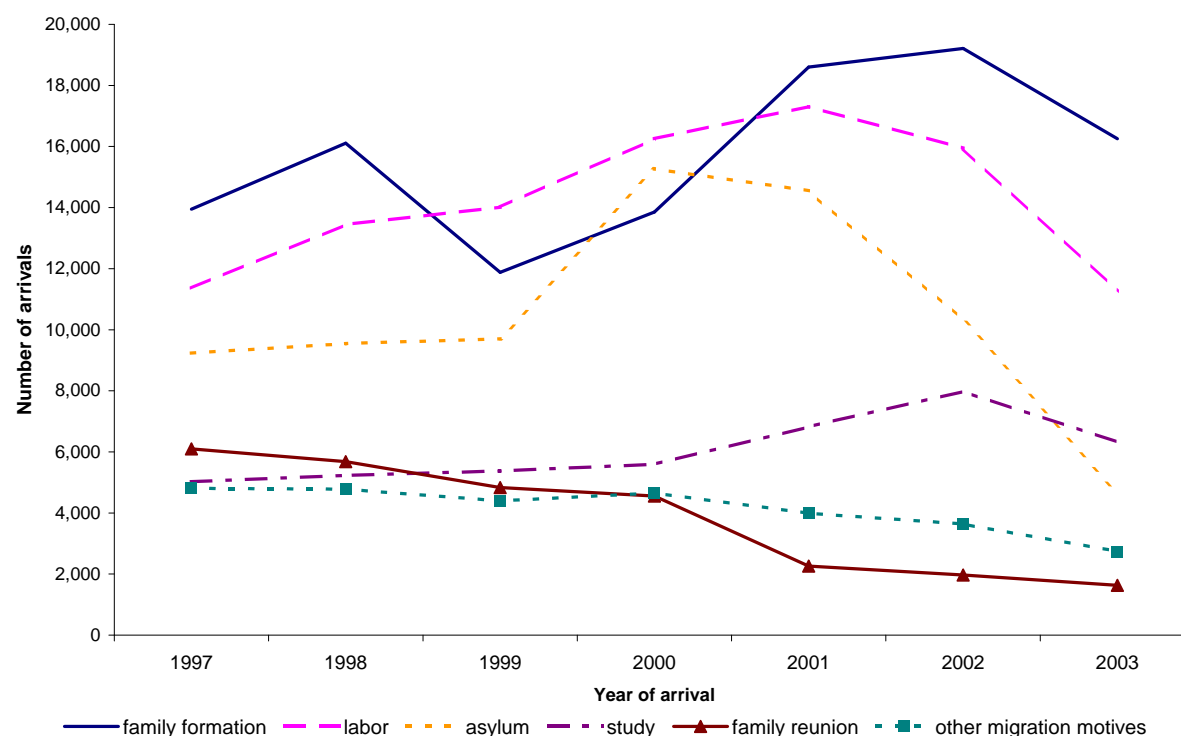

Figure 2: Development of Non-Dutch immigrants (18-64) by migration motive, 1995-2003 


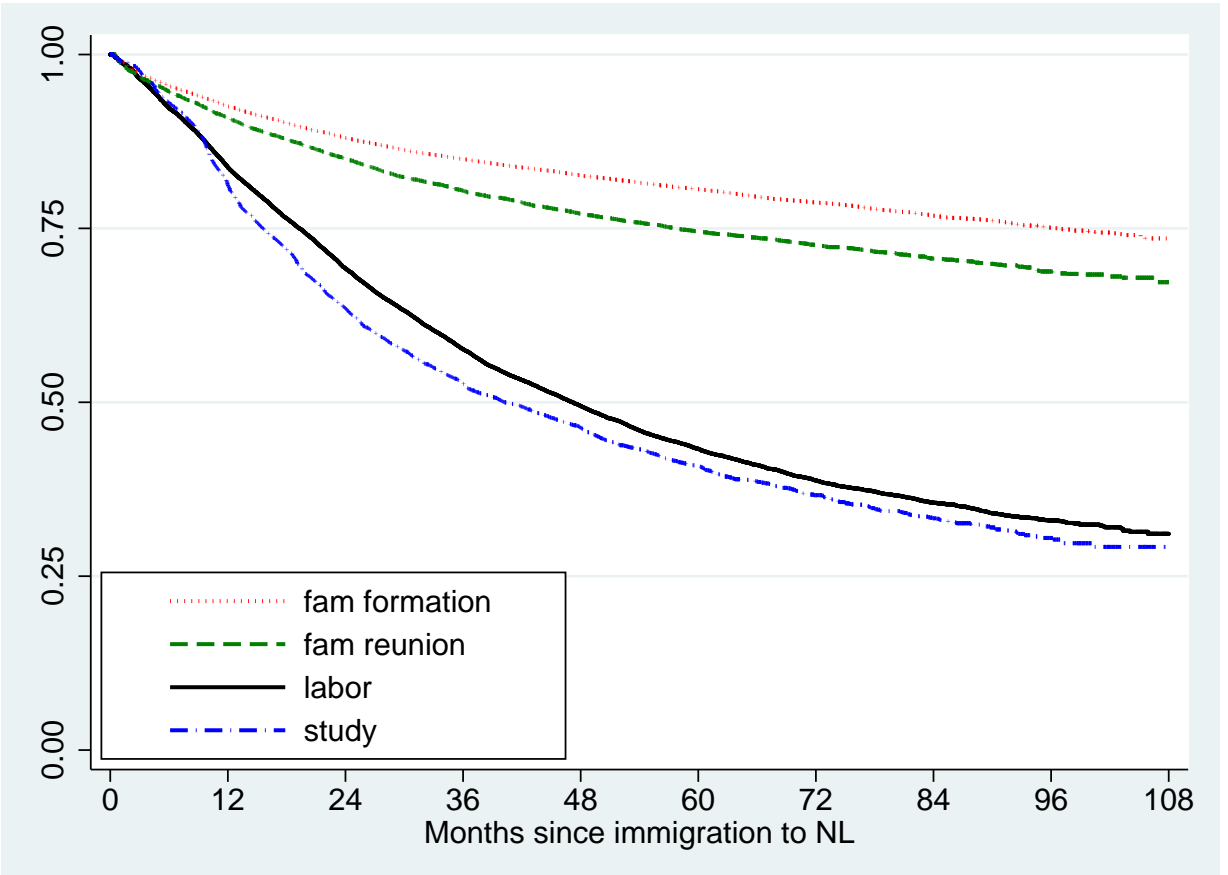

Figure 3: Kaplan-Meier Survival curves leaving The Netherlands (migration motive)

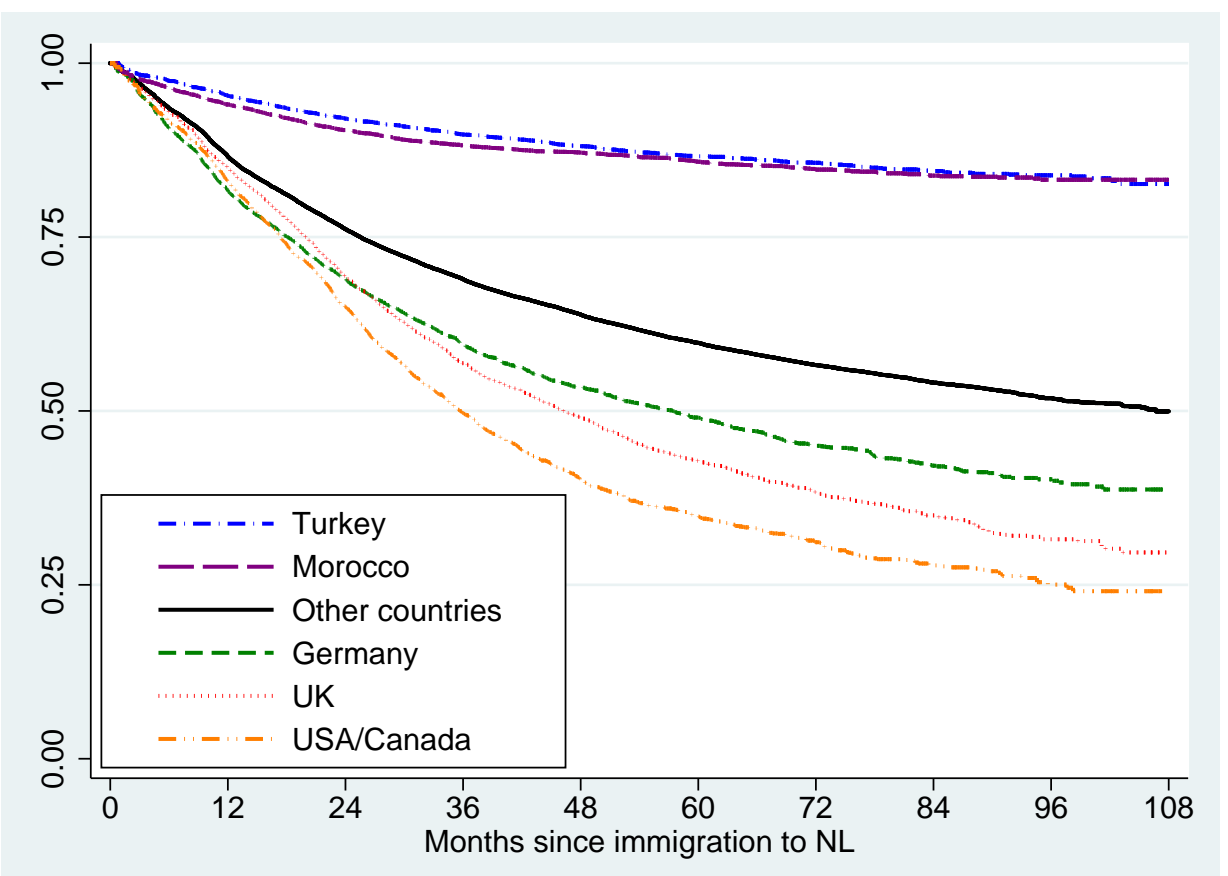

Figure 4: Kaplan-Meier Survival curves leaving The Netherlands (country of origin) 


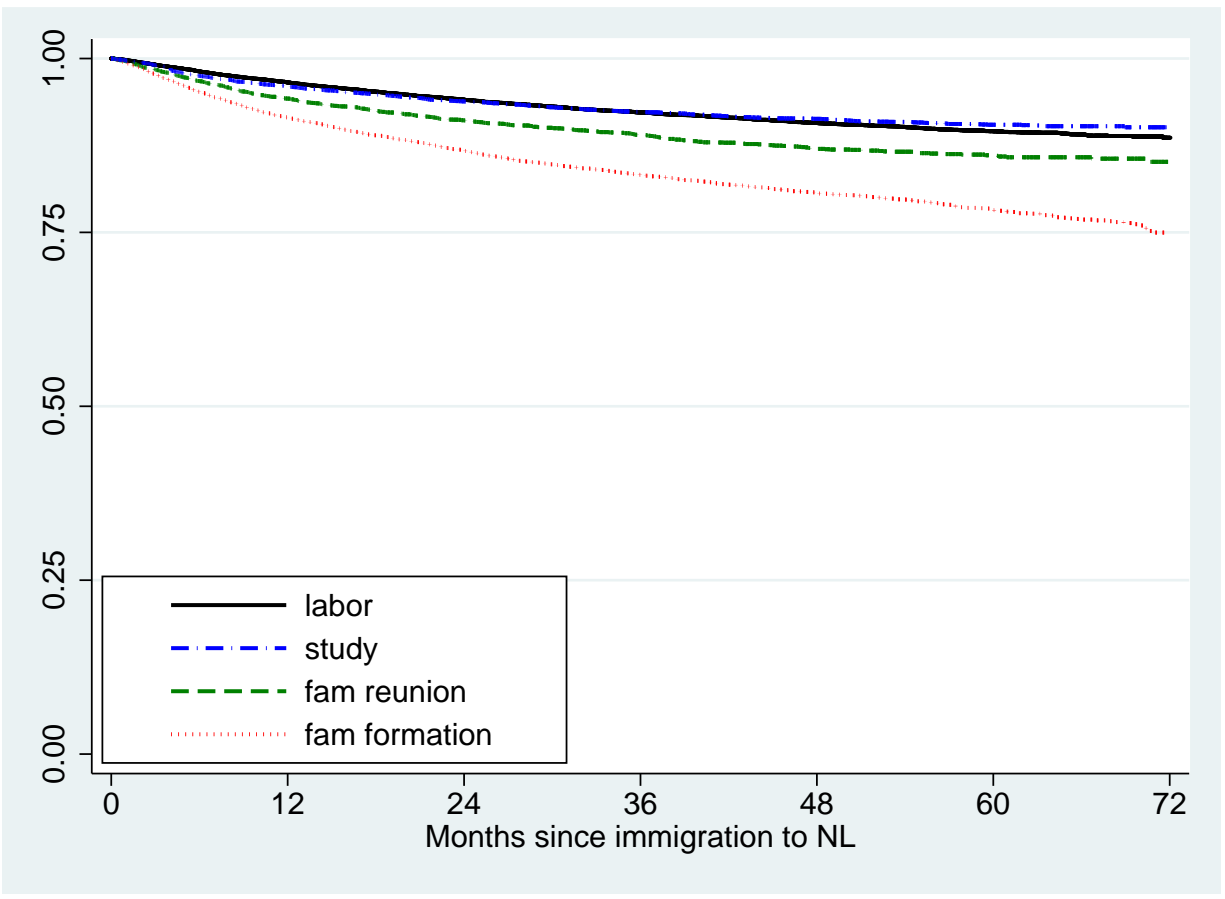

Figure 5: Kaplan-Meier Survival curves returning to The Netherlands (migration motive)

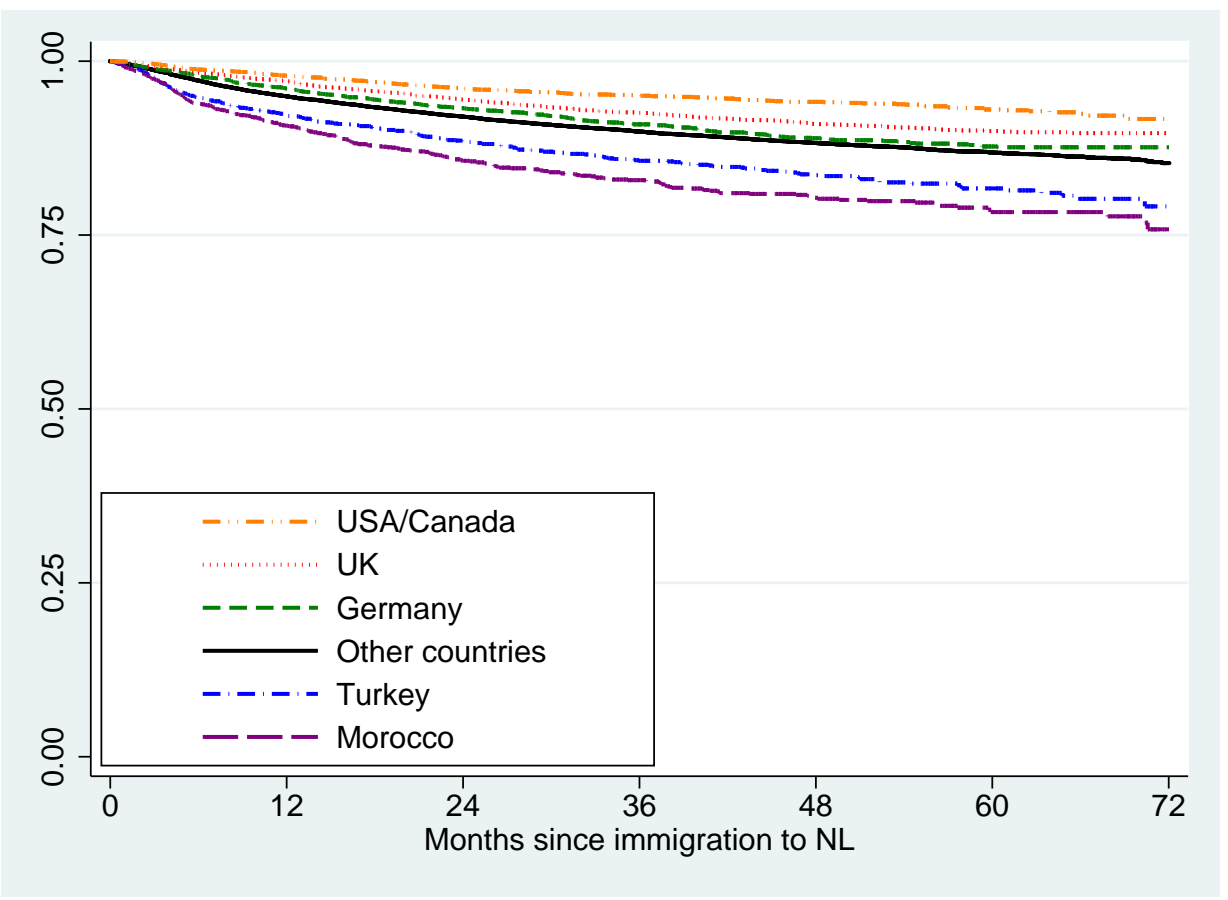

Figure 6: Kaplan-Meier Survival curves returning to The Netherlands (country of origin) 


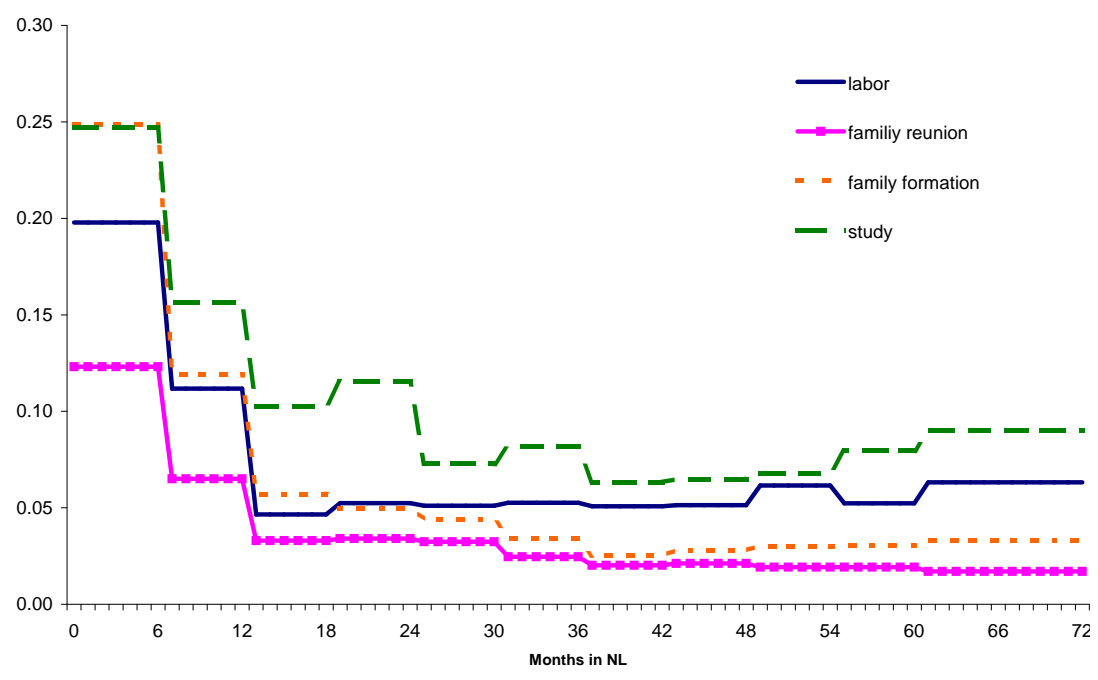

Figure 7: Baseline intensity to leave The Netherlands

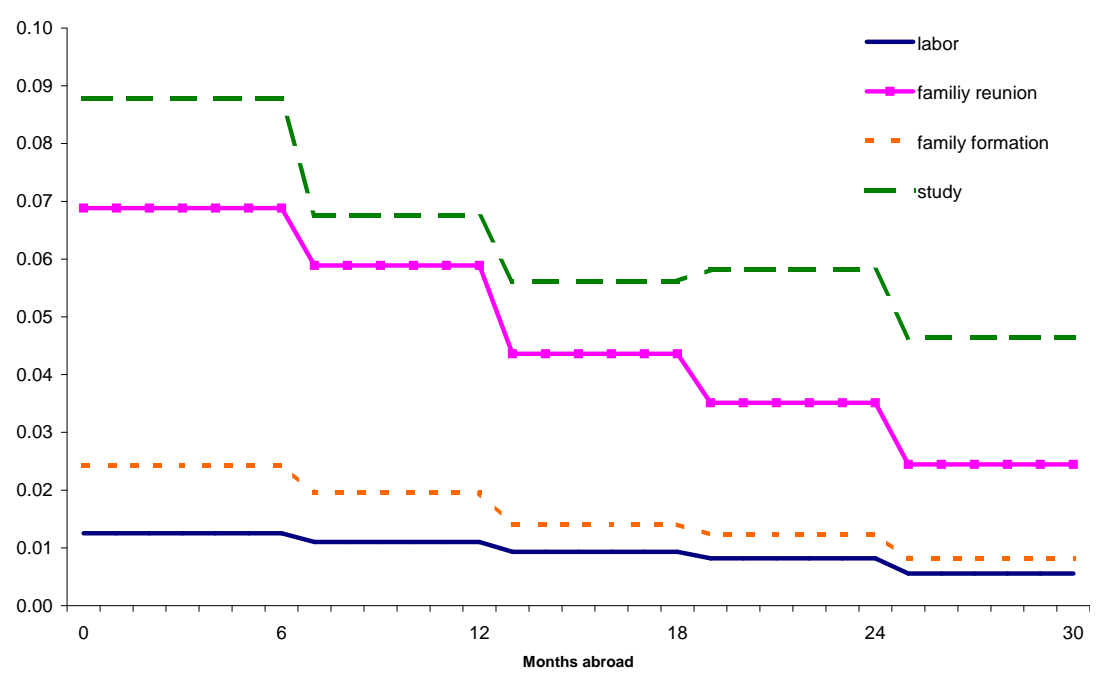

Figure 8: Baseline intensity to return form abroad to The Netherlands 


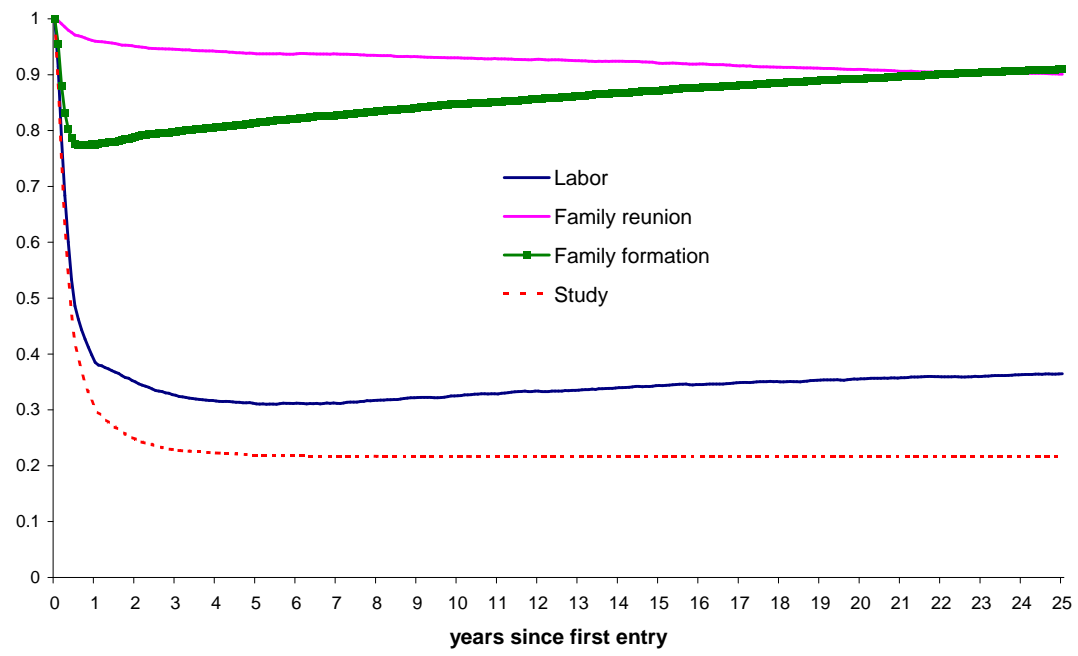

Figure 9: Simulated migration dynamics for a cohort of a typical immigrant.

Labor: male EU/EFTA unmarried 30 years, Family reunion: female married Turkey 30 years, Family formation: female unmarried Turkey 29 years, Study: male EU/EFTA unmarried 21 years

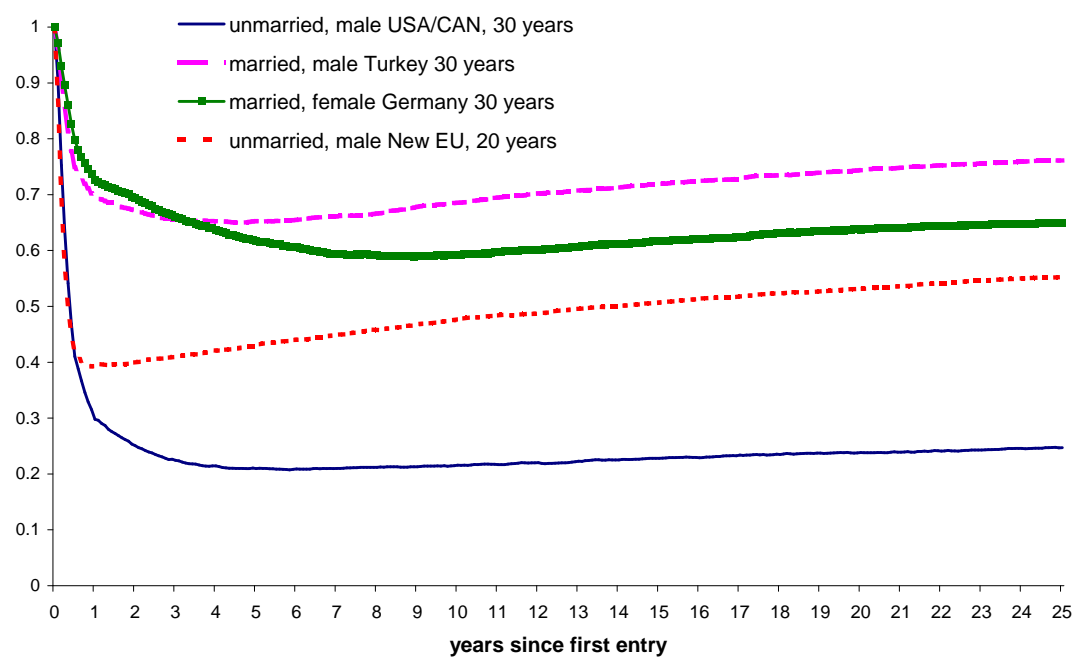

Figure 10: Simulated migration dynamics for a cohort of some typical LABOR immigrants. 


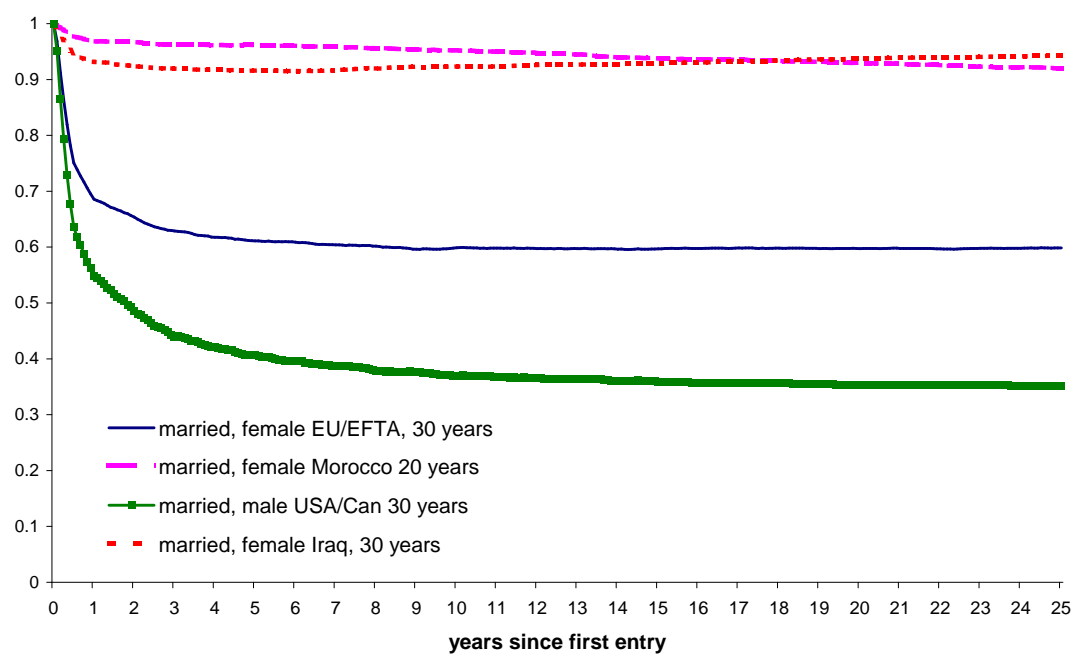

Figure 11: Simulated migration dynamics for a cohort of some typical FAMILY REUNION immigrants.

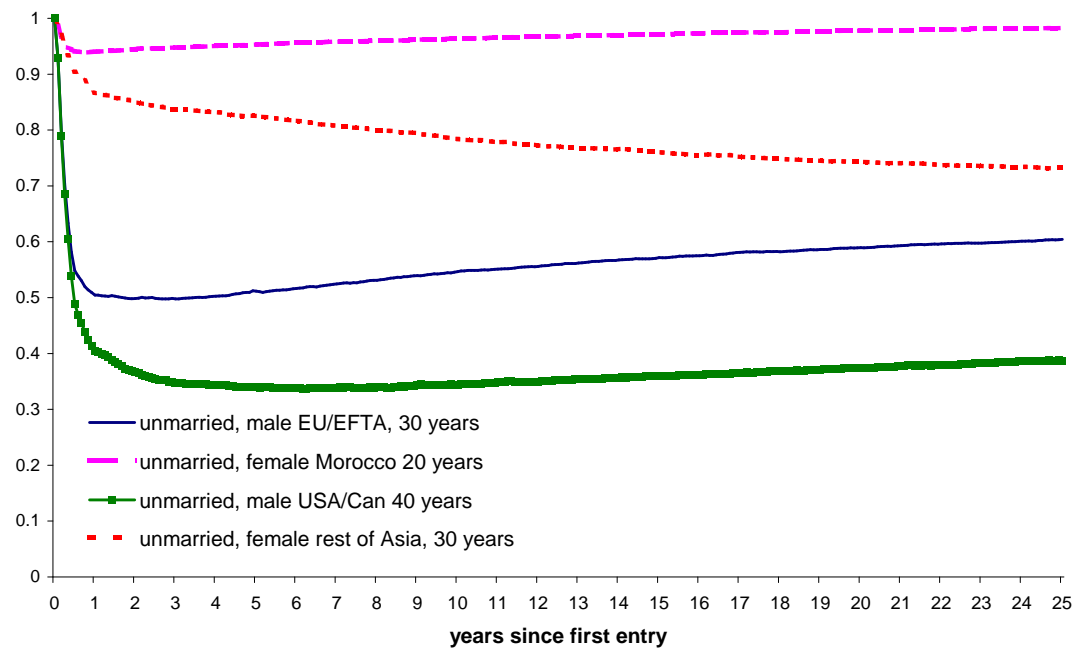

Figure 12: Simulated migration dynamics for a cohort of some typical FAMILY FORMATION immigrants. 


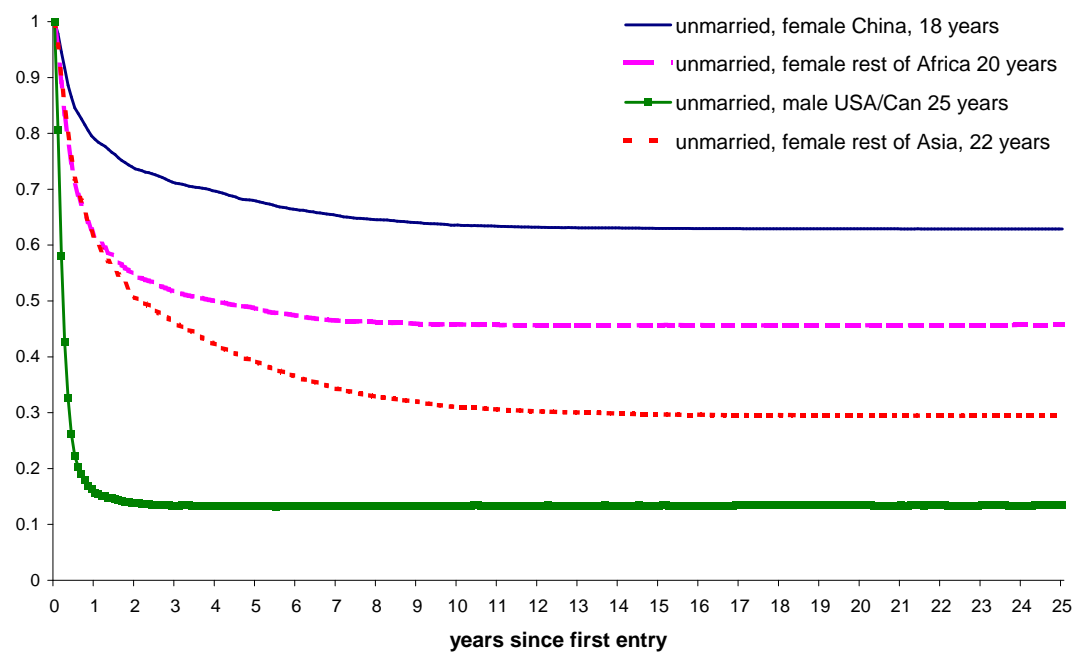

Figure 13: Simulated migration dynamics for a cohort of some typical STUDY immigrants. 